\title{
Collapse wedges in periglacial eolian sands imply Late Pleistocene paleoseismic activity of the Vienna Basin Transfer Fault (western Slovakia)
}

\author{
Michal Šujan ${ }^{1 *}$, Samuel Rybár ${ }^{1}$, Edit Thamó-Bozsó², Tomáš Klučiar ${ }^{1,3}$, \\ Matúš Tibenský ${ }^{4,5}$, Krisztina Sebe ${ }^{6}$
}

1 - Department of Geology and Paleontology, Faculty of Natural Sciences, Comenius University in Bratislava, Ilkovičova 6, $842 \quad 15$ Bratislava, Slovakia; michal.sujan@uniba.sk; samuelrybar3@gmail.com

2 - Mining and Geological Survey of Hungary, Stefánia út 14, 1143 Budapest, Hungary; bozso.edit@mbfsz.gov.hu

3 - MM Revital, Šustekova 10, 851 04, Bratislava, Slovakia; tkluciar@gmail.com

4 - Department of Mathematics and Descriptive Geometry, Faculty of Civil Engineering, Slovak University of Technology in Bratislava, Radlinského 11, 81005 Bratislava, Slovakia; matus.tibensky@gmail.com

5 - Department of Quantitative Methods, Faculty of Management, Comenius University in Bratislava, Odbojárov 10, 82005 Bratislava, Slovakia

6 - Department of Geology and Meteorology, University of Pécs, Ifjúság ú. 6, Pécs 7624, Hungary; krisztina.sebe@gmail.com

* _ corresponding author

The manuscript is a non-peer reviewed preprint submitted to EarthArXiv.

The manuscript has been submitted to the Sedimentary Geology journal on $4^{\text {th }}$ November 2021.

\section{Graphical abstract}
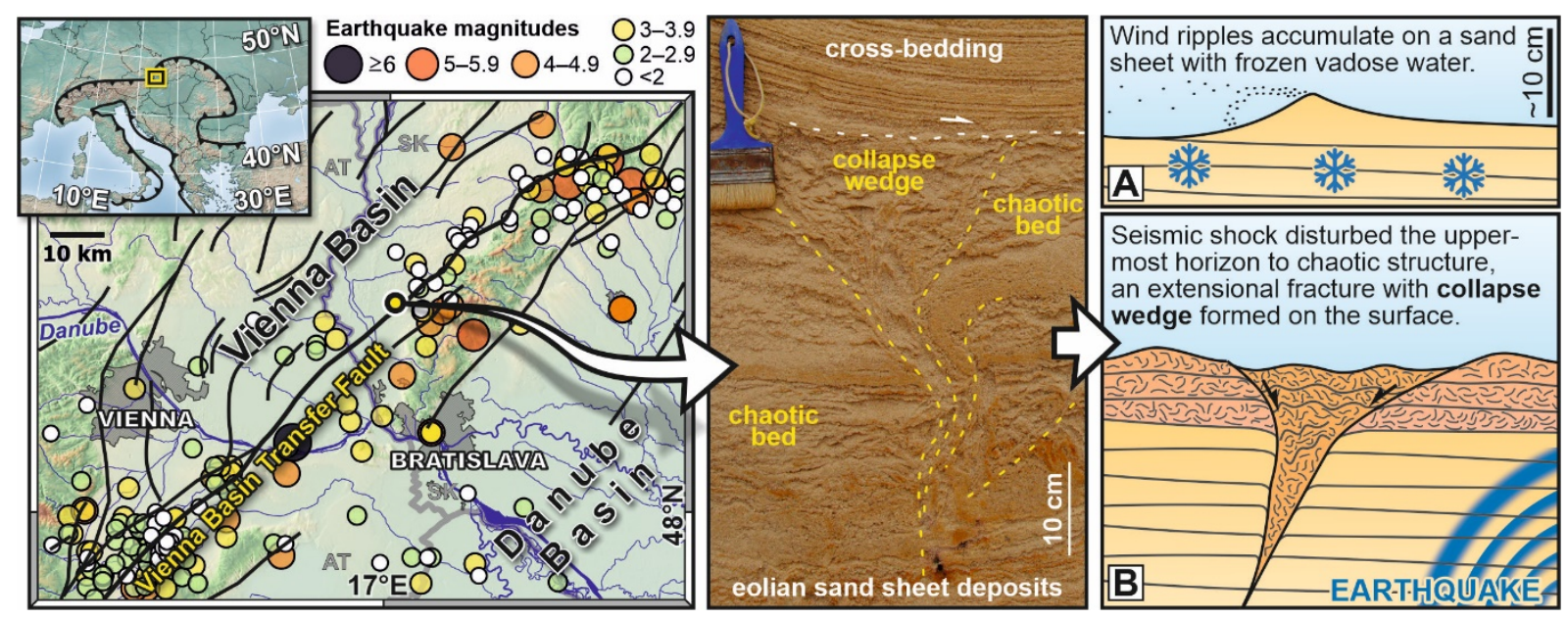


\section{Abstract}

Seismic hazard assessment is an important issue in geological research. Paleoseismological studies of the depositional record contribute significantly to our knowledge of earthquake recurrence over geological time, the distribution of seismically triggered deformations being an area of research that sheds light on temporal patterns of seismic activity. This paper describes soft sediment deformation structures (SSDS) preserved in a periglacial Upper Pleistocene succession of eolian sand in the eastern Vienna Basin, Central Europe. Collapse wedges, which are interpreted as being formed along dilatational fractures, were observed. Further deformations include chaotically disturbed strata, folded strata, and slides. The fractures are oriented systematically in a N-S to NE-SW direction, parallel to the transtensional Vienna Basin Transfer Fault, which lies beneath the study area. Repeated seismic shock is recognized as the trigger of the deformations. The mechanism of deformation implies some degree of cohesion within the deformed strata, and this may be attributed to seasonal frost and the presence of vadose water within the sediment. These deformations appear periodically, in 21 distinct horizons, and it was this that allowed the calculation of the recurrence periods of earthquakes with the use of a Bayesian age-depth model; this, in turn, was based on seven OSL ages. The calculation yielded mean recurrence periods of ca. 150 years, though it should be emphasized that this figure is biased by a relatively high degree of uncertainty in the dating and in the agedepth model. With this caveat, the present study reveals the underexplored potential of periglacial eolian deposits to preserve paleoseismological signals.

Key words: Western Carpathians, luminescence dating, facies analysis, soft-sediment deformation structures, paleoseismology, earthquake recurrence periods

\section{Introduction}

Paleoseismological research focusing on the intensity and recurrence intervals of earthquakes through geological time is of primary importance in the prediction of geohazards related to seismic events. The direct determination of fault activity is routinely carried out for example through the exposure dating of fault scarps (Benedetti et al., 2003; Palumbo et al., 2004; Carcaillet et al., 2008; Tikhomirov et al., 2014), by the dating of successive events using disrupted sediment layers in trenches (Enzel et al., 2000; Decker et al., 2005; Štěpančíková et al., 2008; Štěpančíková et al., 2010; Le Dortz et al., 2011; Hintersberger, 2012; Ansberque et al., 2016; Weissl et al., 2017; Hintersberger et al., 2018), or by dating the deformation of sinters in caves (Plan et al., 2010; Gribovszki et al., 2017; Szczygieł et al., 2021). Significant attention has also been paid to the seismically triggered deformation of sediments related to liquefaction (Guarnieri et al., 2009; Moernaut et al., 2009; Alessio et al., 2012; Holzer et al., 2015; Amorosi et al., 2016). However, intense scientific discussion tends to be focused on ambiguities in the determination of causes in the case of liquefaction - including rapid loading, slope deformations or cryoturbations - all of which may be active concurrently with, or appear in the absence of seismic triggers (van Vliet-Lanoë et al., 2004; Montenat et al., 2007; Moretti and Sabato, 2007; 
Owen et al., 2011). Liquefaction is usually associated with water saturated sandy deposits, and it is most pronounced in the case of heterolithic strata with the presence of impermeable layers amplifying the effect of the water pressure exceeding the shear strength of sediment (Maltman, 1994).

Much less attention has been paid to the research of seismically triggered deformations in successions without cohesive strata, such as eolian sands. The majority of studies focus on the eolian sandy sediments deformed by liquefaction in the presence of water close to a paleosurface (e.g., Cojan and Thiry, 1992; Moretti, 2000; Hurst and Glennie, 2008; Chan and Bruhn, 2014; Bryant et al., 2016; Ford et al., 2016; Chan et al., 2019; Espinoza et al., 2020; Rodríguez-López and Wu, 2020). Only a few studies describe the slope deformation of eolian facies due to earthquakes (Steidtmann, 1982; Cojan and Thiry, 1992; Ford et al., 2016). The present study investigates collapse structures formed due to the opening of fractures in eolian sand accumulated in the periglacial zone of Central Europe during the late Pleistocene (van Vliet-Lanoë et al., 2004; Ruszkiczay-Rüdiger and Kern, 2016). Collapse structures are accompanied by the folding and disturbance of primary structures in specific horizons. The aim of the present research is to provide a detailed documentation of the structures and interpretation of their formative process, since the description of similar forms in any depositional environment is rare in the literature (Alessio et al., 2012; Caputo et al., 2012; Caputo et al., 2016; Lunina and Gladkov, 2016); what is more, these are also absent from the recent reviews of soft-sediment deformation structures (Owen et al., 2011; Shanmugam, 2017).

\section{Geological setting}

The study area is located near the southeastern margin of the Vienna Basin in Central Europe, near the village of Plavecký Štvrtok (Fig. 1). The basin was formed in a pull-apart regime during the middle Miocene due to the lateral escape of the Alpine-Carpathian-Pannonian lithospheric microplate (ALCAPA) northeastwards from the collision zone of Adriatic microplate with the European platform (Fig. 1A) (Fodor, 1995; Kováč et al., 2004; Strauss et al., 2006; Hölzel et al., 2010; Kováč et al., 2017; Lee and Wagreich, 2017). This movement caused the formation of the Vienna Basin Transfer Fault (VBTF) on the southwestern margin of the basin with oblique extensional or transtensional kinematics and a negative flower structure geometry (Fig. 1B) (Decker et al., 2005; Hinsch et al., 2005; Beidinger and Decker, 2011). The subsequent late Miocene subsidence of the Vienna Basin took place in an extensional post-rift setting (Hölzel et al., 2010; Kováč et al., 2017; Lee and Wagreich, 2017). 


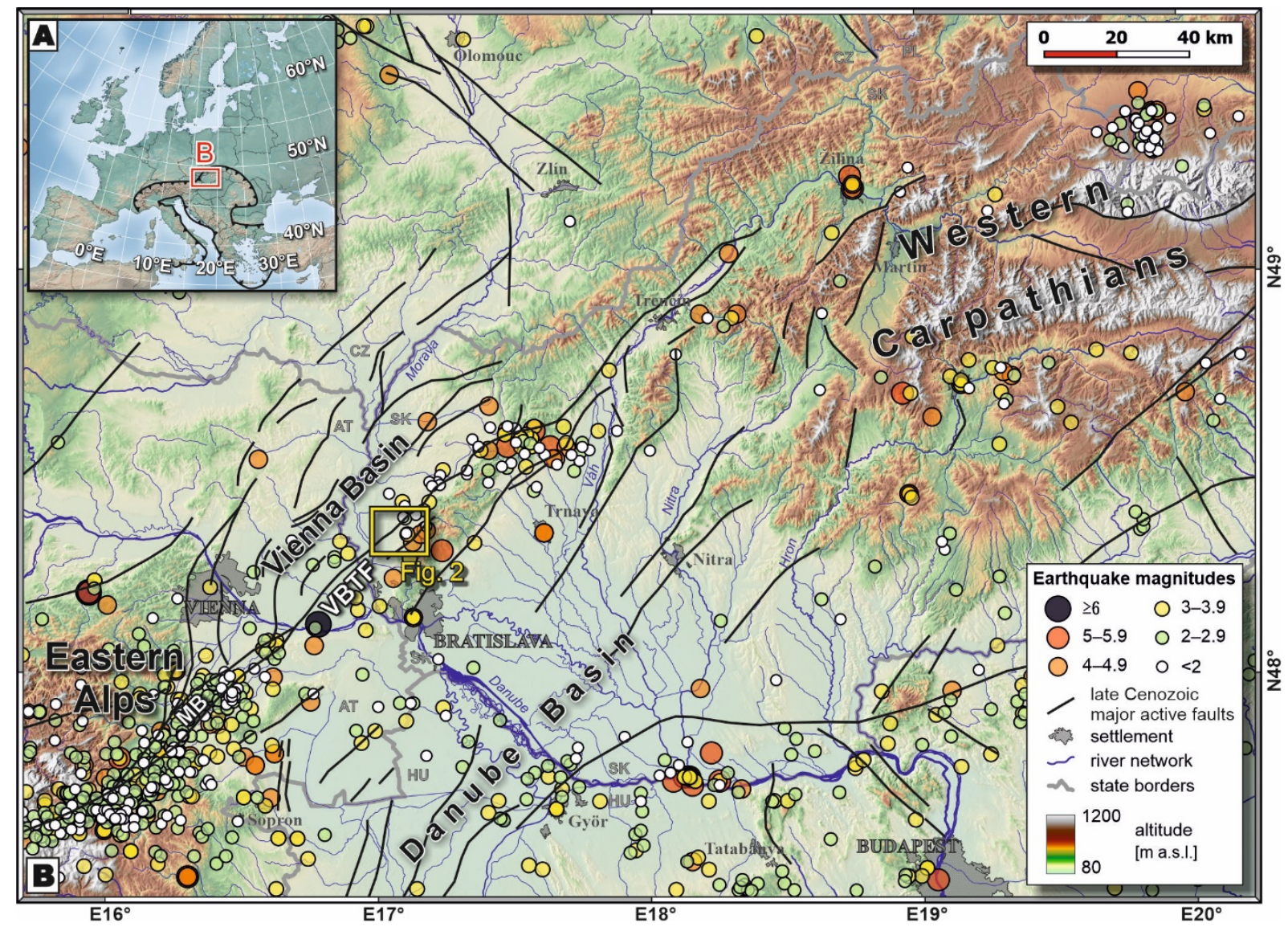

Fig. 1A. Location of the study area within the Alpine-Carpathian orogenic belt. B: Location on the southeastern margin of the Vienna Basin, including major late Cenozoic faults with distribution of earthquake epicenters according to the unified and homogenized SLOVEC (2011) catalogue. The fault network was compiled from Bielik et al. (2002), Lenhardt et al. (2007), Beidinger and Decker (2011) and Hók et al. (2016a); (Hók et al., 2016b). VBTF - Vienna Basin Transfer Fault, MB Mitterndorf Basin. The map is modified from Šujan et al. (2019).

The late Miocene extensional phase of the basin evolution was interrupted by basin inversion in a compressional stress regime, which affected the whole Pannonian Basin realm after 8.04.0 Ma (Fodor et al., 2005; Horváth et al., 2006; Ruszkiczay-Rüdiger et al., 2007; Balázs et al., 2018). This basin inversion caused large-scale lithospheric folding after $\sim 6.0 \mathrm{Ma}$ in the Danube Basin in the southeast (Fig. 1B) (Šujan et al., 2021), and non-deposition or partial denudation of the Miocene infill in the Vienna Basin (Decker, 1996; Decker et al., 2005; Strauss et al., 2006; Salcher et al., 2017). As a consequence, Quaternary deposits overlie the older basin fill unconformably. 

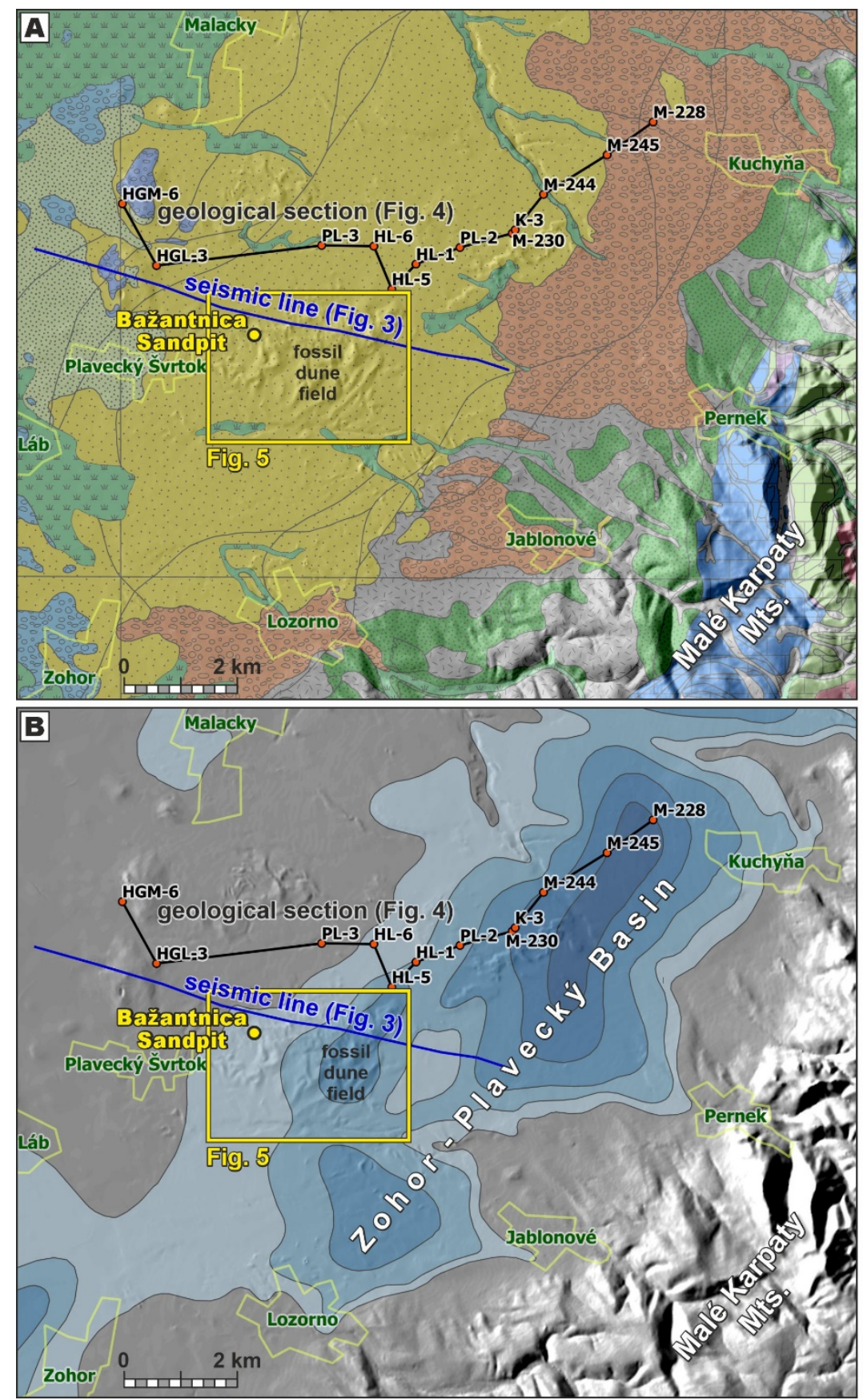

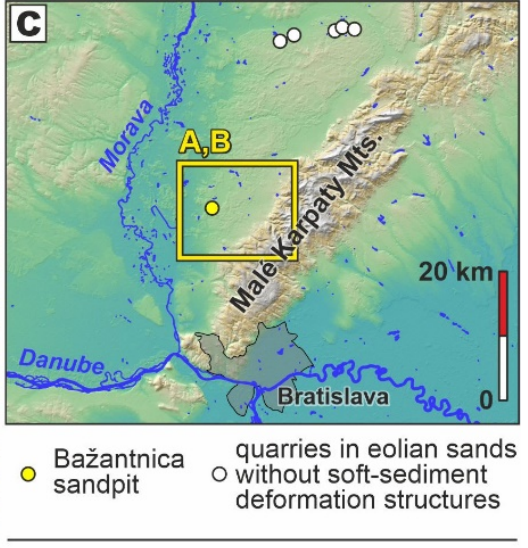

EXPLANATIONS (A)

Quaternary: Upper Pleistocene to Holocene

-1: colluvial and antropoghenic deposits

muddy floodplain facies

swamp and abandoned channel fills

sandy and gavelly channel fills

alluvial fan gravels and sands

eolian sands

upper Miocene

chanel fill sands

and floodplain facies

middle Miocene

$\therefore$ undivided

Mesozoic

$\square \begin{aligned} & \text { undivided } \\ & \text { Cretaceous } \square \text { undivided } \\ & \text { Jurassic }\end{aligned}$

Paleozoic - Carboniferous

++ undivided granitoids

supposed faults, covered by sediments based on correlation of boreholes in Fordinál et al. (2012b)

\section{$\square$ settlement $\square \quad \begin{aligned} & \text { archival } \\ & \text { borehole }\end{aligned}$ \\ reflection _ geologica}

EXPLANATIONS (B)

Quaternary sediments thickness (m)

Fig. 2. Location of the studied sandpit, Bažantnica. A: Geological map simplified according to Fordinál et al. (2012b). B: Quaternary thickness map according to Maglay (2009). C: Distribution of sandpits with and without the presence of softsediment deformation structures in the NE Vienna Basin. See Fig. 1 for location.

Decker et al. (2005) suggested a change from compression during the basin inversion to NESW oriented extension during the Early Pleistocene, and ultimately, to a transtensional regime resembling middle Miocene kinematics from the Middle Pleistocene up to recent times. The VBTF experienced transtensional reactivation in this latter phase, accompanied by the formation of small-scale, narrow pull-apart basins. In the deepest of them, the Mitterndorf Basin, the middle-upper Quaternary basin fill reaches a thickness of $140 \mathrm{~m}$ (Fig. 1) (Decker et al., 2005; Salcher et al., 2012). The marginal faults of the basins are the source of significant 
seismic activity (Fig. 1B) (Hinsch and Decker, 2003; Beidinger et al., 2011; Hinsch and Decker, 2011). The study area is situated along the margin of the Zohor-Plavecký Basin, which has a Quaternary infill of $\sim 60 \mathrm{~m}$, and represents one of the Quaternary basins formed within the VBTF along the northwestern foothills of the Malé Karpaty Mts. (Fig. 2B) (Maglay et al., 1999; Maglay, 2009).

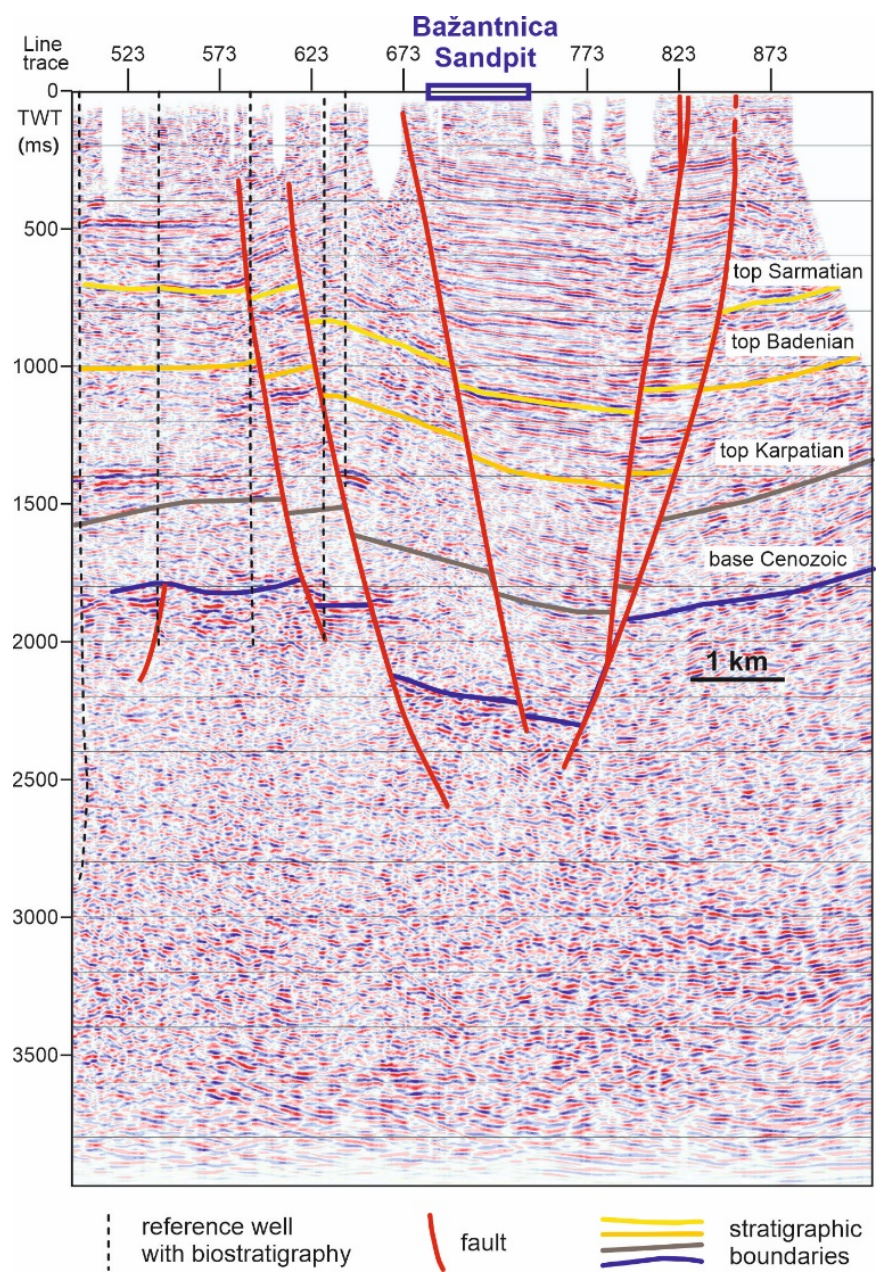

Fig. 3. Reflection seismic line S12/90 (eastern part), depicting the flower structure of the Zohor-Plavecký Basin. See Fig. 2 for location.

In contrast to the Mitterndorf Basin, which has been studied in a number of papers (Decker et al., 2005; Hinsch et al., 2005; Salcher et al., 2010; Salcher and Wagreich, 2010; Salcher et al., 2017), knowledge of the infill of the Zohor-Plavecký Basin is limited. The basin is situated above a negative flower structure of the Vienna Basin transfer fault, as is evident from the reflection seismics (Fig. 3). However, the resolution of the existing seismic lines does not allow the resolution of the contact between the Miocene and the Pliocene to Quaternary successions, which are separated by an unconformity related to the basin inversion. 


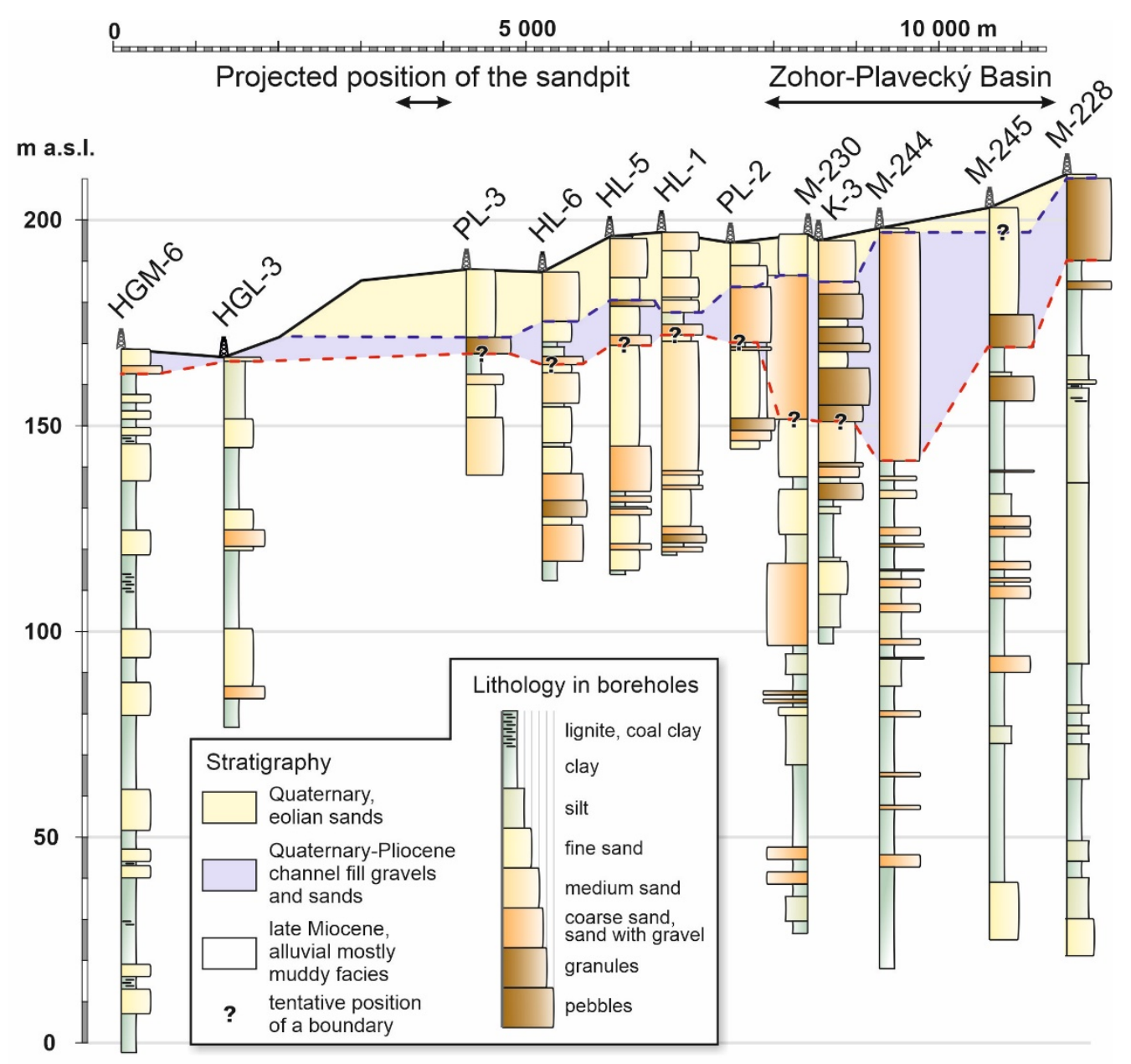

Fig. 4. Geological section showing general stratigraphy in the study area. Note that the orientation of the section is not perpendicular to the margin of the ZohorPlavecký Basin but is adapted to the position of available borehole profiles. See Fig. 2 for location.

Borehole data show that the infill of the Zohor-Plavecký Basin consists mostly of gravels and sands (Fig. 4). The succession was probably deposited by alluvial fans sourced from the Malé Karpaty Mts., similarly to the sediments outcropping in the area (Fig. 2A) (Fordinál et al., 2012b). The underlying upper Miocene Gbely Fm. is also of alluvial origin (Kováč et al., 1998; Harzhauser et al., 2004) and despite its floodplain mud-dominated lithology, gravels and sands of channel fills are common. Therefore, the position of the boundary between the upper Miocene and the Pliocene to Quaternary successions may only be tentatively determined, due to the absence of geochronological or biostratigraphic data for these successions (Fig. 4). 

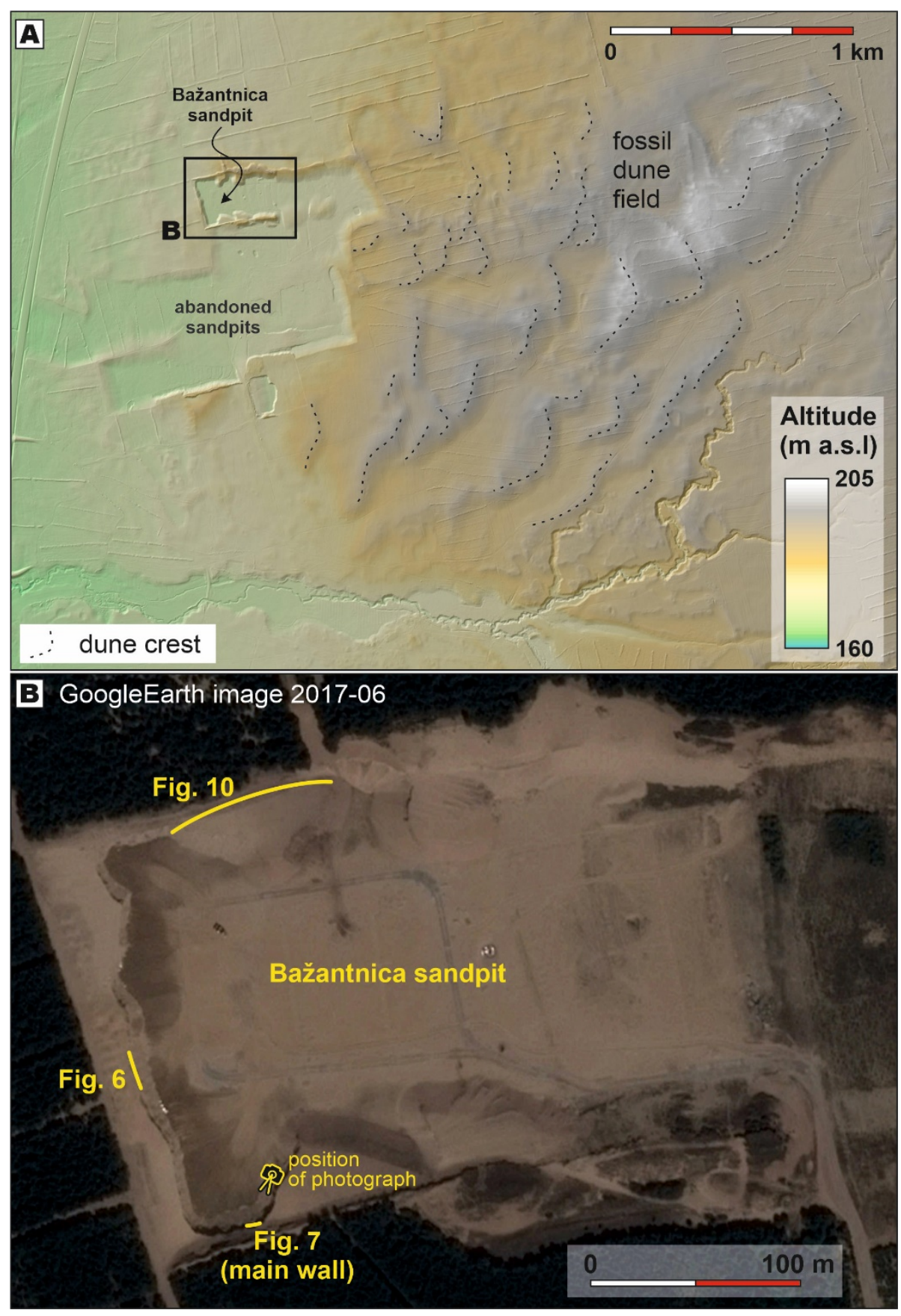

Fig. 5A. Lidar digital elevation model showing the topography of eolian lunate dunes nearby the locality studied. The Lidar DEM data were provided by the Geodesy, Cartography and Cadaster Authority of the Slovak Republic. B. GoogleEarth image with location of the sandpit walls.

The alluvial gravels and sands are covered by an eolian succession up to $30 \mathrm{~m}$ thick (Fordinál et al. 2012) (Fig. 2B, Fig. 4). The fine to coarse sands and gravelly sands form a topography consisting of a fossil field of lunate dunes covered by recent vegetation (Fig. 5A). These deposits have been and continue to be excavated in the Bažantnica sandpit investigated in this study. Existing luminescence dating ages gained from the sandpit range from $40 \pm 5$ ka to $13 \pm$ 1 ka (Moravcová and Fordinál, 2010; Fordinál et al., 2012a; Kadlec et al., 2015), indicating that the depositional record spans the uppermost MIS 3 and the whole of MIS 2, including the Last 
Glacial Maximum (Hughes and Gibbard, 2015). A recent re-evaluation of paleoclimate proxies implies that during glacials the area was characterized by discontinuous permafrost or seasonal frost and relatively dry conditions with the mean annual precipitation reaching 300-490 mm (Ruszkiczay-Rüdiger and Kern, 2016). Soft-sediment deformation structures were first briefly reported from the Bažantnica sandpit by Fordinál et al. (2012a) and by Kadlec et al. (2015) and are investigated in detail in the present study.

\section{Methods}

\subsection{Field research}

The field campaign of documenting the deformations in the sand pit was performed in December 2016, when air temperatures dropped below $0^{\circ} \mathrm{C}$ for the whole day. This condition turned out to be very favorable, since frozen pore water in the sediment gave rise to a high degree of cohesion and allowed effective cleaning of the outcrop wall with shovel and spatula without occasioning failure in what is normally a deposit lacking all cohesion, and therefore practically impossible to observe in a clean section. Moreover, variations in the grain size on the outcrop were highlighted by the differential freezing of the beds, leading to increased visibility of the structures after the brushing of the wall.

Active excavation leads to a constantly changing view of the outcrop. After the inspection of all existing outcrops, a wall (referred to in the present study as "the main wall”, Fig. 5B) was selected on the basis of the abundance of deformation structures and on its orientation perpendicular to the brittle deformations for detailed cleaning and analysis. The main sedimentary features and deformations of the sediments were documented. The orientation of all fractures related to the wedge-like structures was measured using a geological compass on the main wall, as well as on other walls in the sandpit. The primary dip of the strata was also measured at the position of every wedge-like structure. The main wall was also a subject of sampling for luminescence dating.

\subsection{Luminescence dating}

The sampling strategy for optically stimulated luminescence (OSL) dating was to determine the age of the deformed horizons. Sample preparation for OSL dating was carried out under subdued red-light conditions. The sunlight-contaminated outermost few centimeters of the sediments were removed from the two ends of the sampling tubes and were not used for dating. Wet sieving was applied to separate the 100-200 $\mu \mathrm{m}$ grain size fractions of the samples. Organic material was removed with the use of $20 \% \mathrm{H}_{2} \mathrm{O}_{2}$, while carbonates were dissolved using $10 \% \mathrm{HCl}$. Quartz-rich fractions were separated with the aid of sodium polytungstate (SPT: $\mathrm{Na}_{6}\left[\mathrm{H}_{2} \mathrm{~W}_{12} \mathrm{O}_{40}\right] \mathrm{H}_{2} \mathrm{O}$ ) solution $\left(2.67 \mathrm{~g} / \mathrm{cm}^{3}\right)$. The outer $10 \mu \mathrm{m}$ layer of the quartz grains, which have absorbed a dose of alpha radiation, plus the feldspars, were removed with the use of $40 \% \mathrm{HF}$ for 60 minutes. As the IR test indicated that these separates were feldspar contaminated, a further 30 minutes' etching with $40 \%$ HF was employed. The quartz fractions 
were then cleaned using $10 \% \mathrm{HCl}$. After dry sieving, the 100-160 $\mu \mathrm{m}$ grains were mounted in monolayer on stainless steel discs using silicone oil spray. The size of the aliquots was a $5 \mathrm{~mm}$ diameter (medium aliquot).

OSL measurements were made by a Risø TL/OSL DA-20 C/D reader with a calibrated ${ }^{90} \mathrm{Sr} /{ }^{90} \mathrm{Y}$ beta source. Blue light stimulated luminescence of quartz was detected through a Hoya-340 filter. The Single-Aliquot Regenerative-dose (SAR) OSL protocol (Wintle and Murray, 2006) was applied, with illumination for $40 \mathrm{~s}$ at $280^{\circ} \mathrm{C}$ in the last step of each cycle. OSL signals were evaluated using the early-background subtraction method (Cunningham and Wallinga, 2010) when the 0.8-1.6 s integral of the OSL decay curve was subtracted from the initial $0.8 \mathrm{~s}$ integral signal to avoid a contribution from medium and slow OSL components. The dose-response curves were fitted using a single saturation exponential function. The purity of the quartz separates was checked by IR test (measurement of OSL depletion due to infrared stimulation) on every aliquot in an additional cycle of the SAR-OSL protocol. The preheat plateau, thermal transfer and dose recovery tests were also carried out on each quartz fraction.

On the basis of the results of the preheat plateau test, a preheat temperature of $240{ }^{\circ} \mathrm{C}$ and a cut heat of $200{ }^{\circ} \mathrm{C}$ were chosen. The thermal transfer test indicated that the thermal transfer was negligible using a $240{ }^{\circ} \mathrm{C}$ preheat temperature. The dose recovery ratio, which was measured on 4 aliquots of each sample, varied between 0.87 and 1.08 (0.98 \pm 0.05 on average, $n=28$ ), and indicated that the SAR protocol correctly measured the given dose. Only one aliquot, that of sample PS4, had a dose recovery ratio falling outside the acceptable $1.0 \pm 0.1$ range (0.87). A few aliquots were rejected due to an inadequate result of the IR test, bad recycling ratio, or high equivalent dose error. The recuperation was low ( $0.16 \pm 0.34$ on average, $n=259)$.

Sample preparation, gamma spectrometry and water content measurements, the creation and evaluation of the luminescence measurements, and the age calculation were carried out at the Mining and Geological Survey of Hungary (MBFSZ, former Geological and Geophysical Institute of Hungary). The OSL measurements were run at the Eötvös Loránd University, Budapest.

The OSL ages obtained served for age-depth modeling using the Bacon package developed by Blaauw and Christensen (2011) for R statistical software (R Core Team, 2020). The purpose of the model was to obtain a statistically robust age-depth model, what is ensured by the use of Markov Chain Monte Carlo (MCMC) iterations to calculate the accommodation rate for each section of the sedimentary interval under investigation. The model included assumption of a continuous deposition, as the depositional record and ages obtained did not imply existence of a hiatus. The prior assumptions concerning coherence in accommodation rate were set by the Bacon parameters of 'memory', namely, mem.mean and mem.strength. After testing a range of values with very low variability of the output, the model finally selected includes the default setting of the parameters (mem.mean=0.7, mem.strength=4). 


\section{Results}

\subsection{Primary structures and depositional processes}

\subsubsection{Description}

A major part of the outcropping walls in the Bažantnica sandpit is formed by subhorizontally arranged, parallel layers of alternating fine, medium and coarse sand, with less frequent layers of granules (Fig. 6). Subhorizontal layers of silty fine sand occasionally appear ( $<10 \%$ of the sediment thickness). Individual layers range between a few millimeters to $2 \mathrm{~cm}$ thick. Bedding is interrupted by subhorizontal erosional surfaces, which are covered by conformable or onlapping strata (Figs. 6, 7). In the case of conformable contact of underlying and overlying strata, truncation is visible only as the cross-cutting of deformations. The sand is moderately sorted in individual layers, and grains are well rounded and spherical, with a matte surface. The dip of the strata attains $10-14^{\circ}$ in the lower, and $5-8^{\circ}$ in the upper part of the main wall, with a general dip direction towards S and SSE (Fig. 8). The measurements across other walls of the sandpit yielded dips of $2-10^{\circ}$ and orientations represented almost all directions relatively equally (Fig. 8).

Subhorizontal layers alternate with less frequent low angle planar cross-stratified sand layers 20-40 cm thick (Fig. 6, 9B, G, H). Trough cross-stratified sand lenses are present occasionally, one example in Fig. 6 reaches a thickness of $55 \mathrm{~cm}$ and a width of ca. $4.5 \mathrm{~m}$. Large-scale crossstratification with heights of over $4 \mathrm{~m}$ also occurs in the sand pit (Fig. 10). Cross-stratified units usually have an erosional base, which is subhorizontal and straight or concave. 

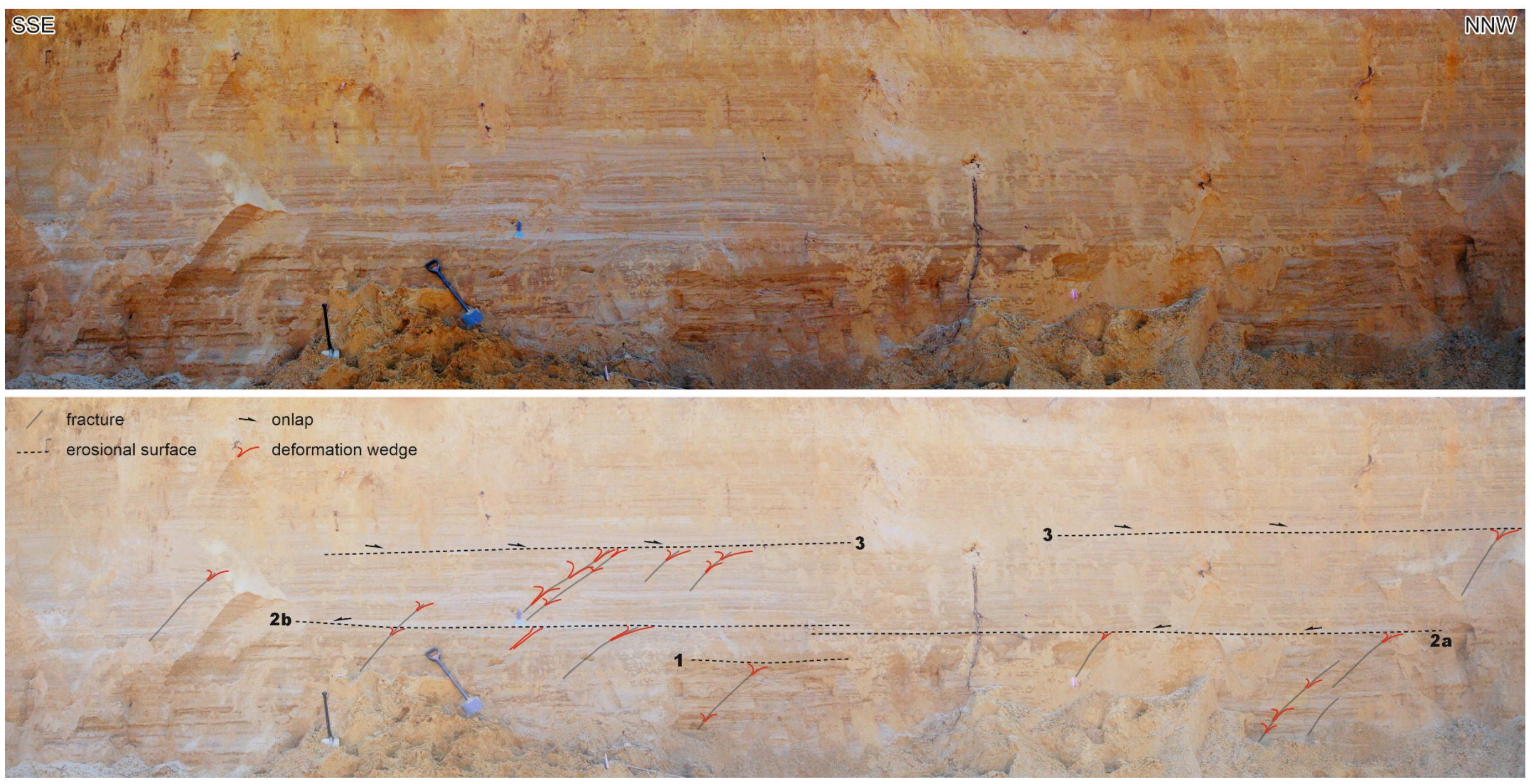

Fig. 6. An example of Bažantnica sandpit wall, showing generally sub-horizontal stratified sands and wedge-shaped deformations. The deformations locally terminate on erosional surfaces, which are overlain by onlapping strata. Note the uniform orientation of fractures. For location of the outcrop see Fig. 5B. 


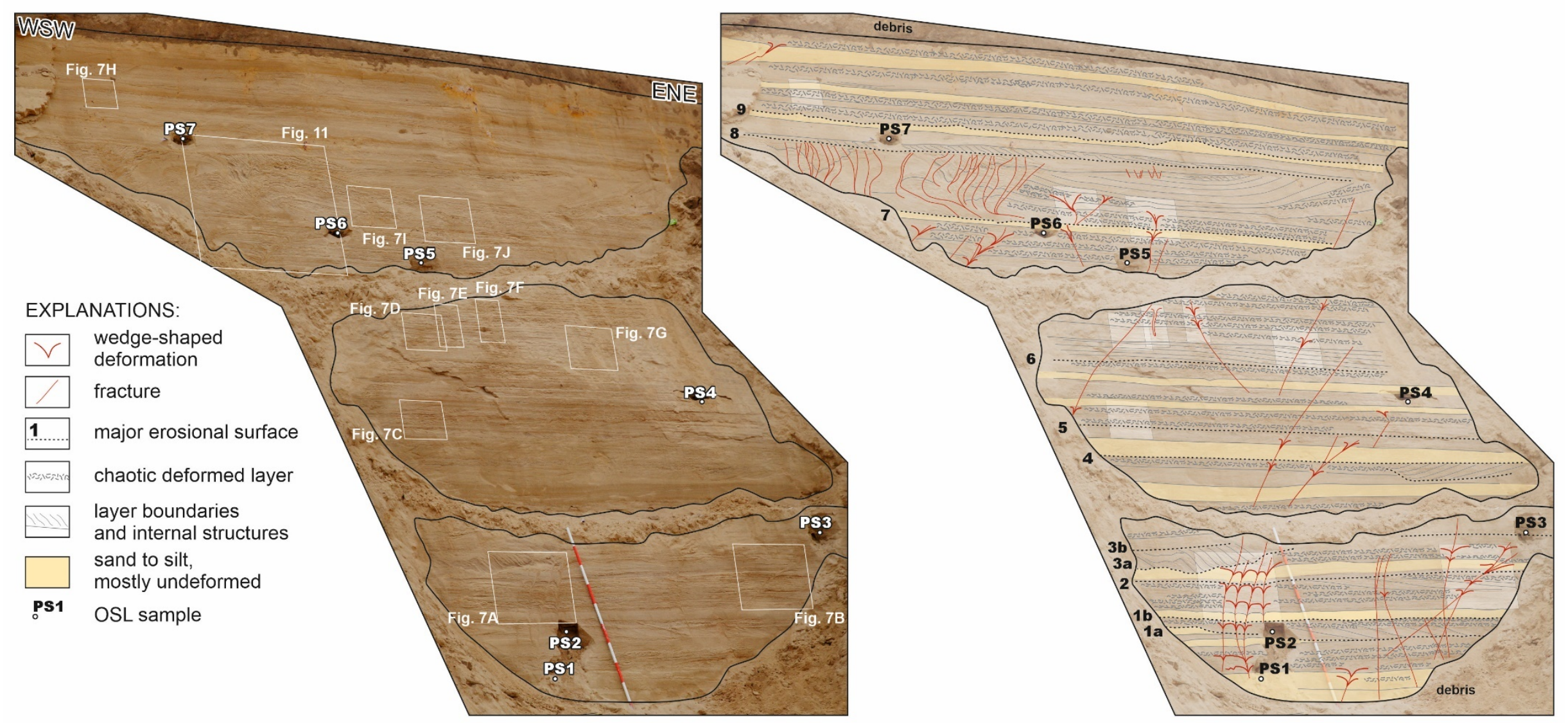

Fig. 7. Outcrop wall analyzed in detail and sampled for OSL dating, referred to in the text as "the main wall". The photograph was taken from an elevated position to the left of the outcrop; hence, the view is partly oblique. Along a single fracture, every wedge marked in red is considered to represent a separate deformation event. Erosion surfaces marked with the same number and differentiated by small letter are merged into one surface in some part of the outcrop. For location of the outcrop, see Fig. 5B. 

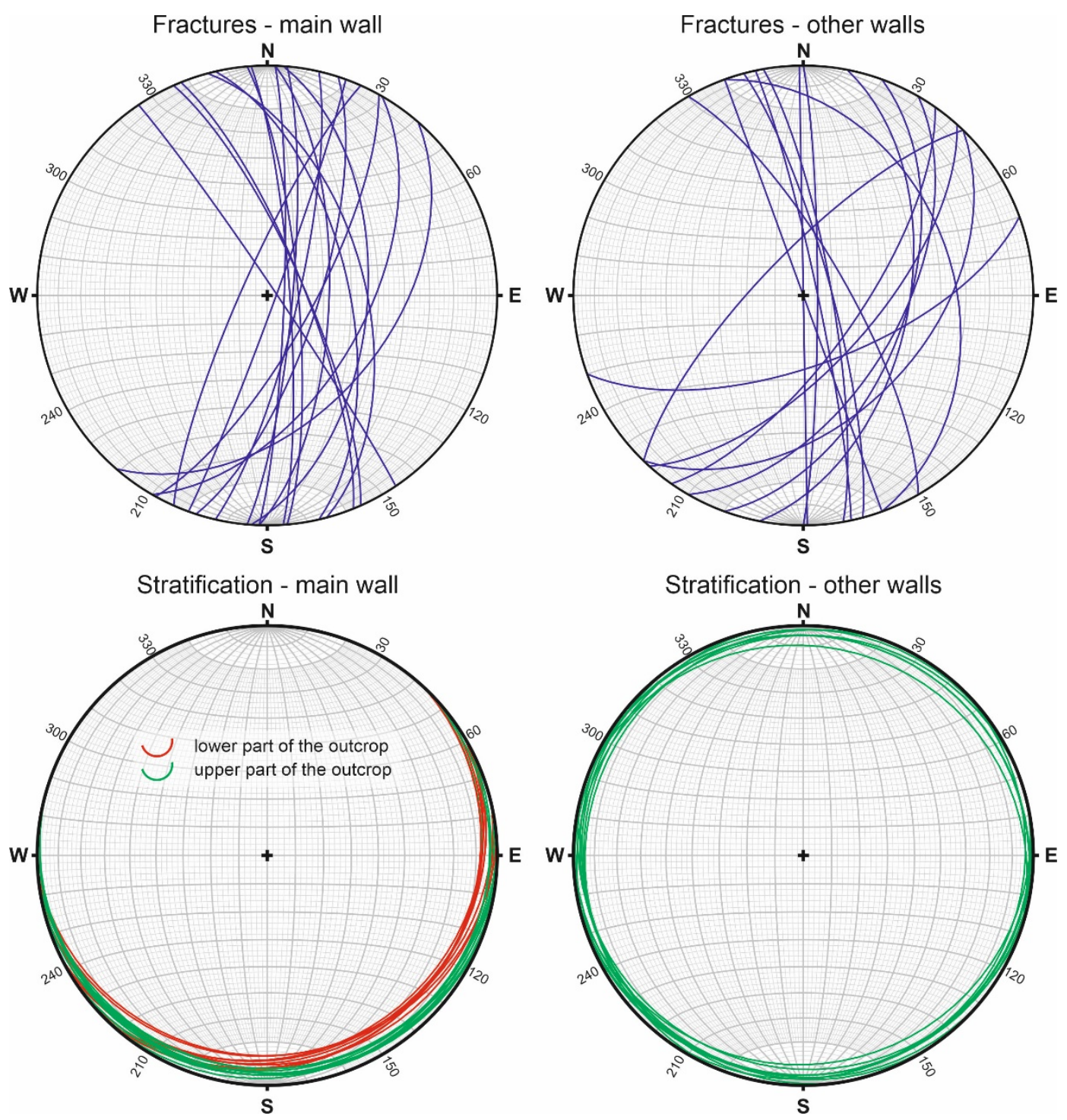

Fig. 8. Stereographic projections of the fractures associated with wedge-shaped structures and of primary stratifications at the location of the wedges. 

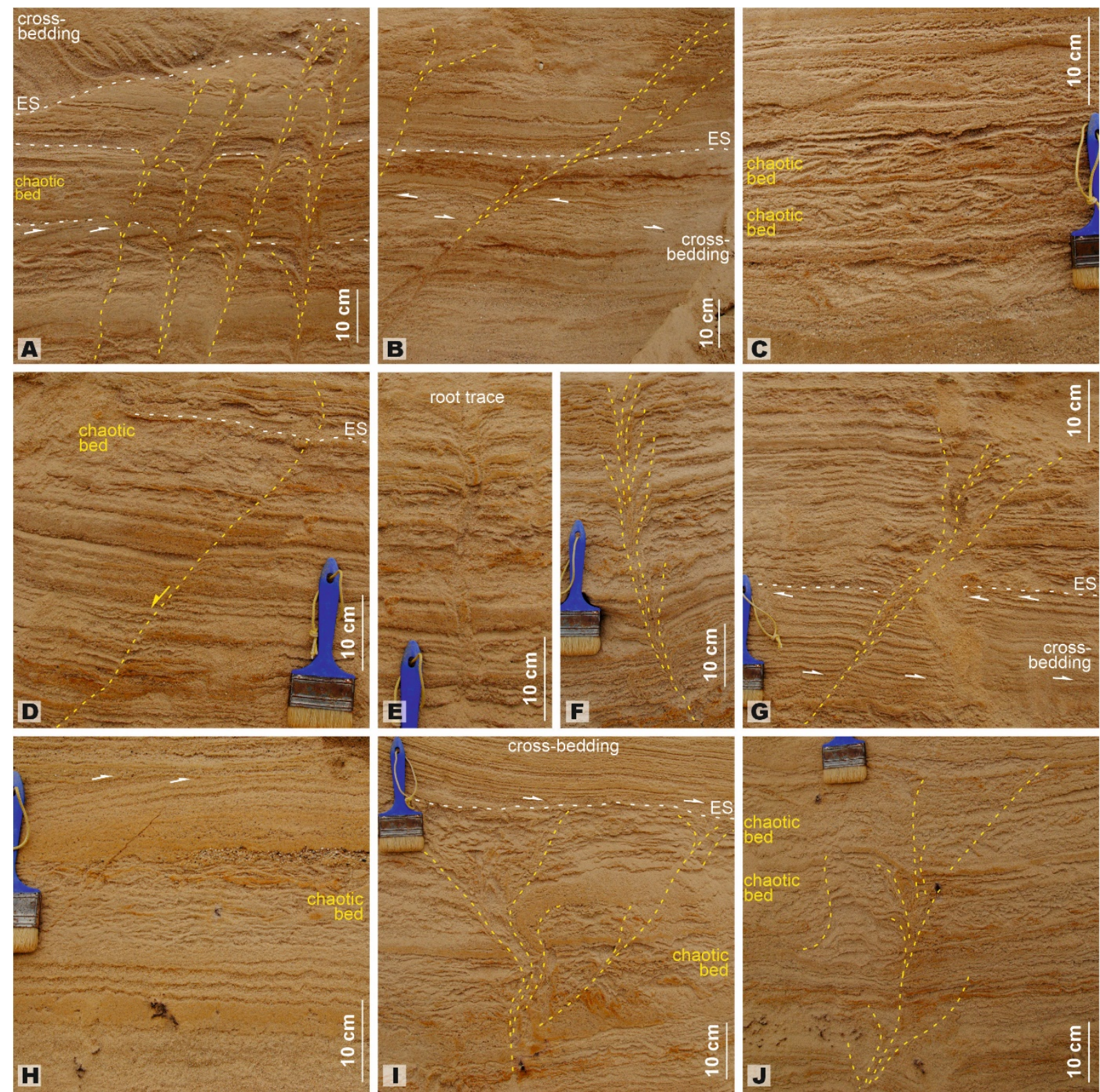

Fig. 9. Details of structures observed on the main outcrop wall (Fig. 6). Primary structures are depicted in white and deformation structures in yellow. Along the same fracture, every wedge marked by a yellow dashed line is considered a separate deformation event . For location of the outcrop, see Fig. 5B. 


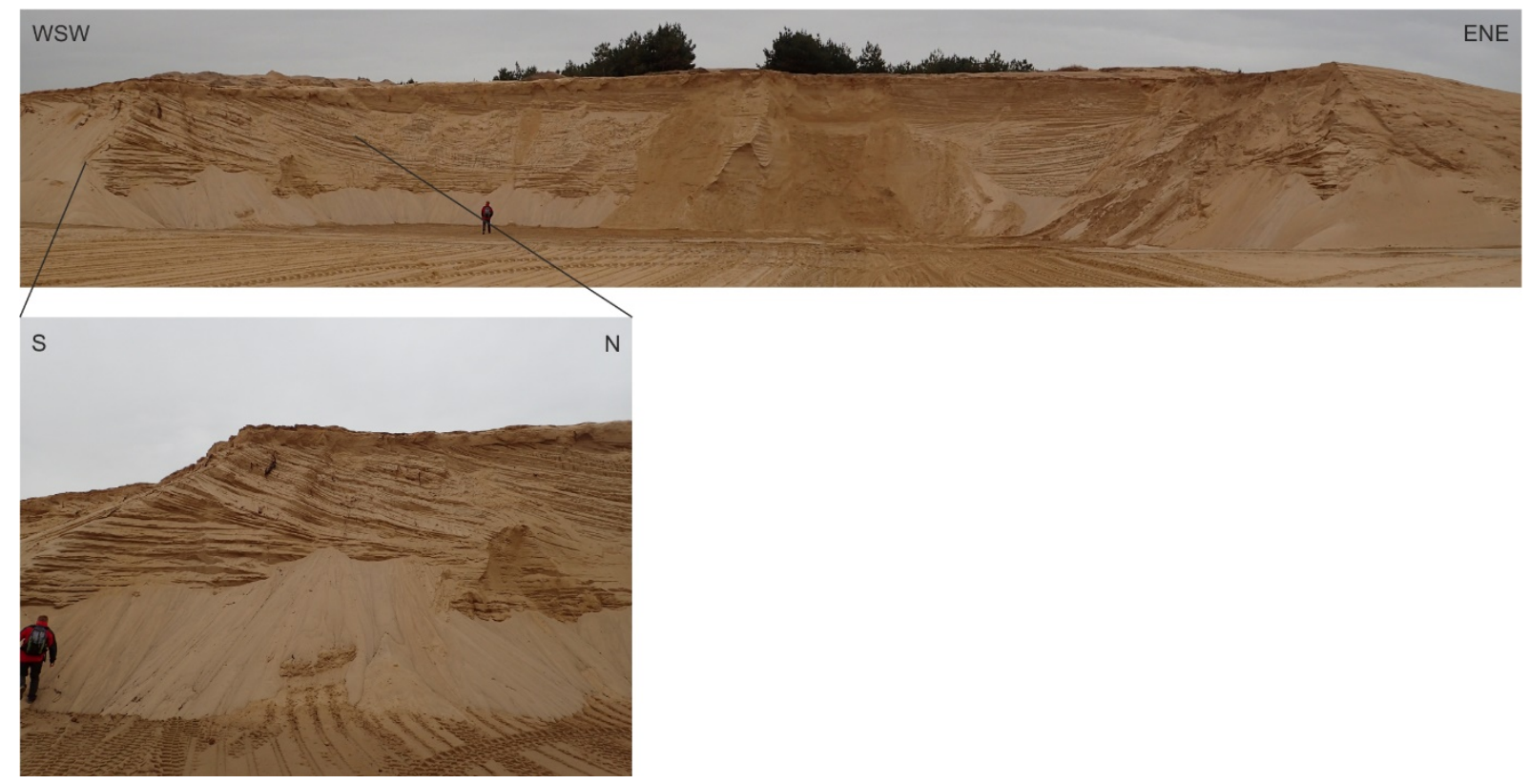

Fig. 10. An example of a large-scale cross-stratification present in the Bažantnica sandpit. For location of the outcrop, see Fig. 5B.

\subsubsection{Interpretation}

The rounding and matte surface of the sand grains indicates eolian transport. The alternation of moderately well-sorted subhorizontal or smoothly dipping layers of sand with various grain sizes is a product of translatent wind ripple stratification (Hunter, 1977), and indicates deposition from subcritically climbing wind ripples on a sand sheet (Loope, 1984; Jordan and Mountney, 2010). Moderate sorting is also a result of a relatively short transport distance, in this case, from the Morava River (Moravcová \& Fordinál, 2010, Fordinál et al., 2012). The low angle planar cross-strata could be associated with rippleform lamination, while trough crossstrata represent eolian dunes (Hunter, 1977; Pye and Tsoar, 2009). The observed settings are comparable to those described from a subrecent periglacial eolian sand sheet in Iceland (Mountney and Russell, 2004). The periglacial climate causes the widespread presence of vadose water in sand sheets, increasing cohesivity of transported particles, and hence decreasing the height of wind ripples and dunes (Van Dijk et al., 1996; Jackson and Nordstrom, 1998; Mountney and Russell, 2009). This is in accordance with the observed thickness of cross-strata reaching only $10-55 \mathrm{~cm}$. Cross-stratification to a height of several meters represents the dune landforms also visible in the modern topography (Fig. 5A, Fig. 10). Wide, parabolic dunes are characteristic of areas with low precipitation and restricted, but nonetheless existing, vegetation, typical of cold climates, and the European Pleistocene periglacial belt, as well (Seppälä, 2004; Pye and Tsoar, 2009; Yan \& Baas, 2015; and references therein). Their orientation - the arms pointing upwind, the curvature downwind - fits the prevailing ENE Pleistocene wind direction of the area (Sebe et al. 2015). Layers of granules exhibit best sorting and represent a residual lag formed by deflation events with increased wind speed (Fryberger et al., 1992; Mountney and Russell, 2004). This kind of granule lag is especially characteristic of cold-climate eolian 
environments (Ruz and Allard, 1995). The silty fine sand strata most probably represent events of decreased wind activity (Vandenberghe, 2013).

\subsection{Deformation structures}

Soft-sediment deformation structures are frequent on all walls of the Bažantnica sandpit. All other sandpits in eolian sands of the Slovakian part of the Vienna Basin were checked for the presence of similar deformation structures, but with a negative result (Fig. 2C). However, these sandpits are not located directly in the course of the VBTF, as the Bažantnica sandpit is.

\subsubsection{Wedge-shaped structures}

Wedge-shaped structures are the most common deformations in the studied outcrops, with 21 wedges documented and measured on the main wall, and 17 wedges on the remaining walls in the sandpit (Figs. 5, 6, 7, 8, 9). The wedges are sharply delimited from the surrounding sand sheet strata and narrow downwards. They reach width of a few centimeters to $30 \mathrm{~cm}$ with an average width of $\sim 10 \mathrm{~cm}$ in the topmost part. The height of individual wedges ranges from 10 $\mathrm{cm}$ (Fig. 9A) to $>50 \mathrm{~cm}$ (Fig. 9I). The top of the wedges is usually overlain by undeformed strata, and as a general rule, their fill is truncated. The internal structure of a wedge can vary. Most wedges are thin (Fig. 7, Fig. 9A, F). In their upper parts the host sand layers bend downward on both sides of the structure. Between them, a structureless sand infill of a few centimeters' thickness can occur, and this may then continue downward, below the bent layers. The lowermost part of the wedges is usually just a fracture, without infill. In some wedges, blocks of the neighboring stratified sand have moved down a few cm-s (Fig. 9B). The largest wedges can partly be filled by the material of the surrounding, chaotically disturbed sand beds (Fig. 9G, I). The overall character of the wedges implies a dominant downward movement of the infill during deformation. Most of the wedges exhibit a curved funnel shape in vertical section (Fig. 9A, B, G, I, J). 


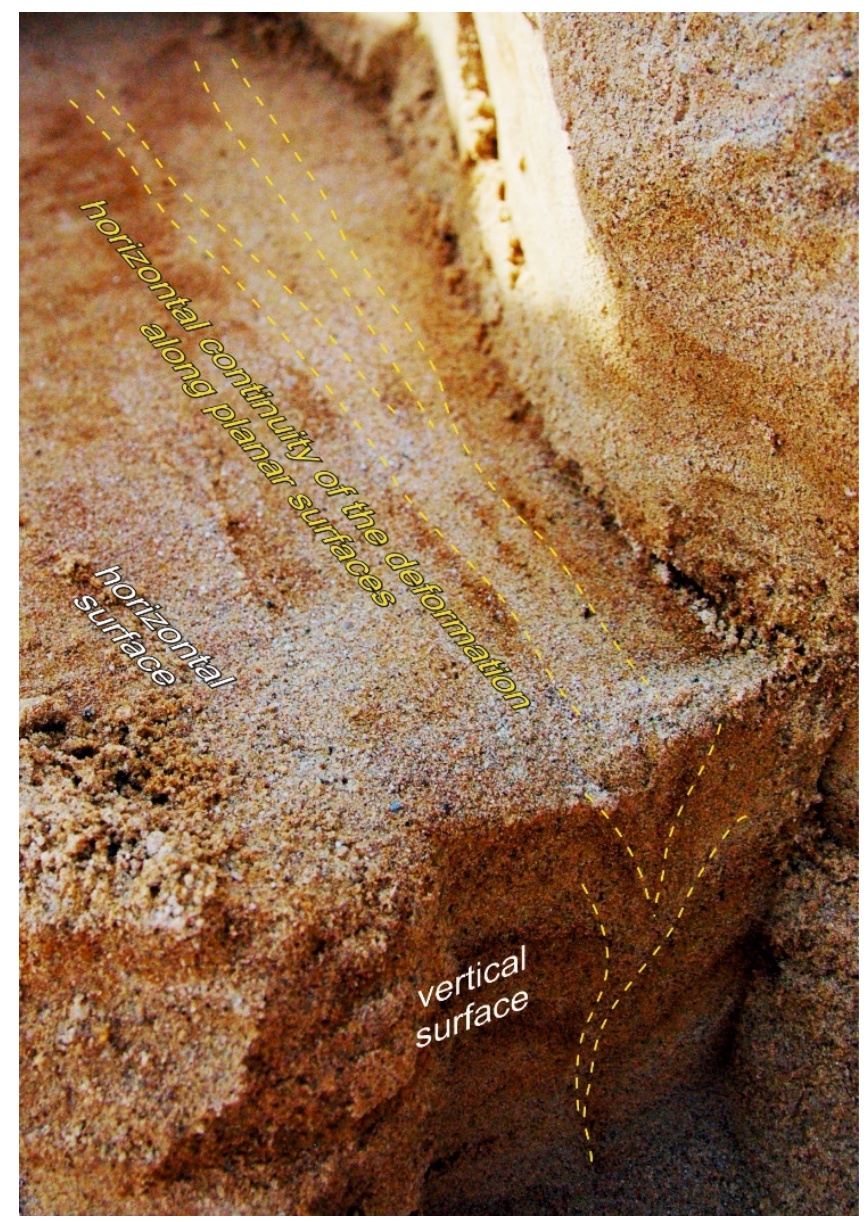

Fig. 11. 3D geometry of a wedge-shaped structure, showing deformation along a planar surface through the deposit.

Each wedge is associated with a fracture running along its center, at least in its lower portion. The inclination of fractures ranges between $46-86^{\circ}$ (average $72.9^{\circ}$ ) on the main wall and $45-$ $85^{\circ}$ (average $68.8^{\circ}$ ) on the remaining walls in the sand pit. Fractures are systematically oriented $\mathrm{N}-\mathrm{S}$ and NE-SW (Fig. 8). As the fractures are inclined, most of the associated wedges are asymmetrical, and the steeper wall is bent down to a greater degree than the other one (Fig. 7, Fig. 9G, J). The fractures are planar structures without significant variation in the orientation of a single structure (Fig. 11). A single fracture with an offset of a few centimeters was observed (Fig. 9D), but represents an exception. The offset did not vary within the studied exposure. Most of the fractures continue up to the base of the outcrop, while a minority of them appear to terminate within the succession (e.g., Fig. 7 - middle level).

The wedges are grouped in horizons, clearly visible in Figs. 6, 7 and 9A. In these horizons, several wedges occur next to each other laterally, and they are truncated by the same erosional surface. In many cases, the wedges formed repeatedly along the same fracture (Fig. 9), while some of them terminated within the studied succession (Figs. 6, 7, 9I, J). The upper termination always lies along a major erosional surface. A fracture may occasionally split into two branches, each with developed wedges (Fig. 9I). 


\subsubsection{Other deformations}

Beds a few centimeters to $15 \mathrm{~cm}$ thick with chaotic structure appear frequently, locally with poorly visible remains of the original structure, and these appear as fragments of bedded sand a few centimeters long (Fig. 9C, D, H). There is an obvious relationship between the distribution of the layers with chaotic structure and the wedge-shaped deformations: (1) most of the chaotic beds appear in the same horizons as the wedges and are disrupted by the wedges, and (2) the wedges as well as the chaotic beds are truncated by the same erosional surface, when observed together (Figs. 7, 9 A, B, G, I, J). The chaotic beds lie conformably on the underlying strata, without truncating them.

Beside the chaotic layers, and with significantly less frequency, $10-20 \mathrm{~cm}$ thick folded sand layers appear as well (Fig. 12). The folds are usually open, sometimes tight. While many folds are symmetrical and upright, asymmetric - inclined or recumbent - ones are also common. A preferential orientation of asymmetric folds, i.e., the tilt of the axial plane towards a certain direction, could not be observed. The folded layer packages are truncated by the overlying sand beds (Fig. 12). The underlying strata are not affected by the deformation. The folded strata appear in the same horizons as deformation wedges and are truncated by the same erosional surfaces, similarly to the chaotic beds.

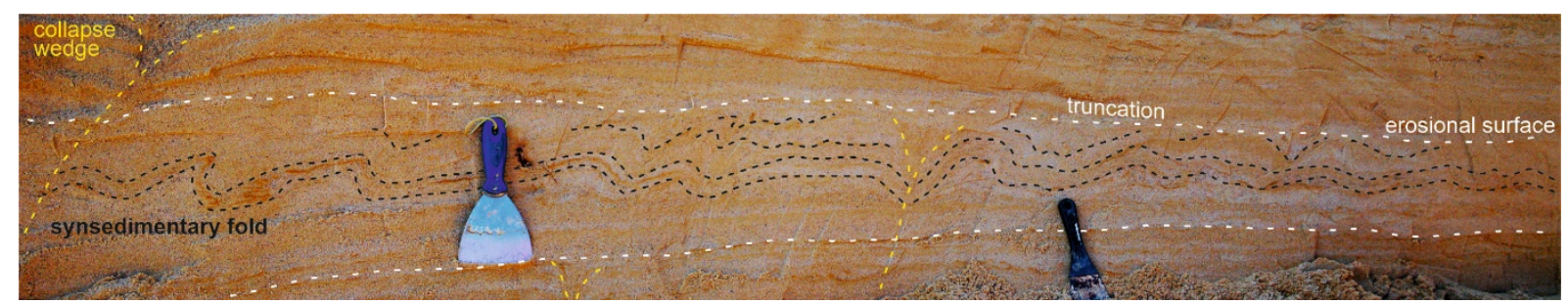

Fig. 12. Synsedimentary folding (black) truncated by erosional surface (white) and wedge structures (yellow).

It should be noted that two types of erosional surfaces were observed in relation to the distribution of deformation structures: (1) truncation at the top of the disturbed surface, which might cut off only the uppermost few centimeters of the sediment, leading to conformable contact with overlying strata (Fig. 7B, C, Fig. 12), and (2) a major erosion surface, cutting off a significant part or the disturbed horizon, while only a small part of the wedges remained intact; the resulting stacking pattern of beds then comprises the truncation and angular contacts of post-deformational strata with the underlying sediments (Fig. 7A, I).

A cross-stratified sandy unit with steep sigmoidal foresets and a complicated concave, sharply defined base also shows deformation structures (Fig. 7 - between erosional surfaces 3a and 3b, and Fig. 9A). The foresets gradually attain a convex shape towards the left, a form that is impossible for them to have attained during sedimentation. 

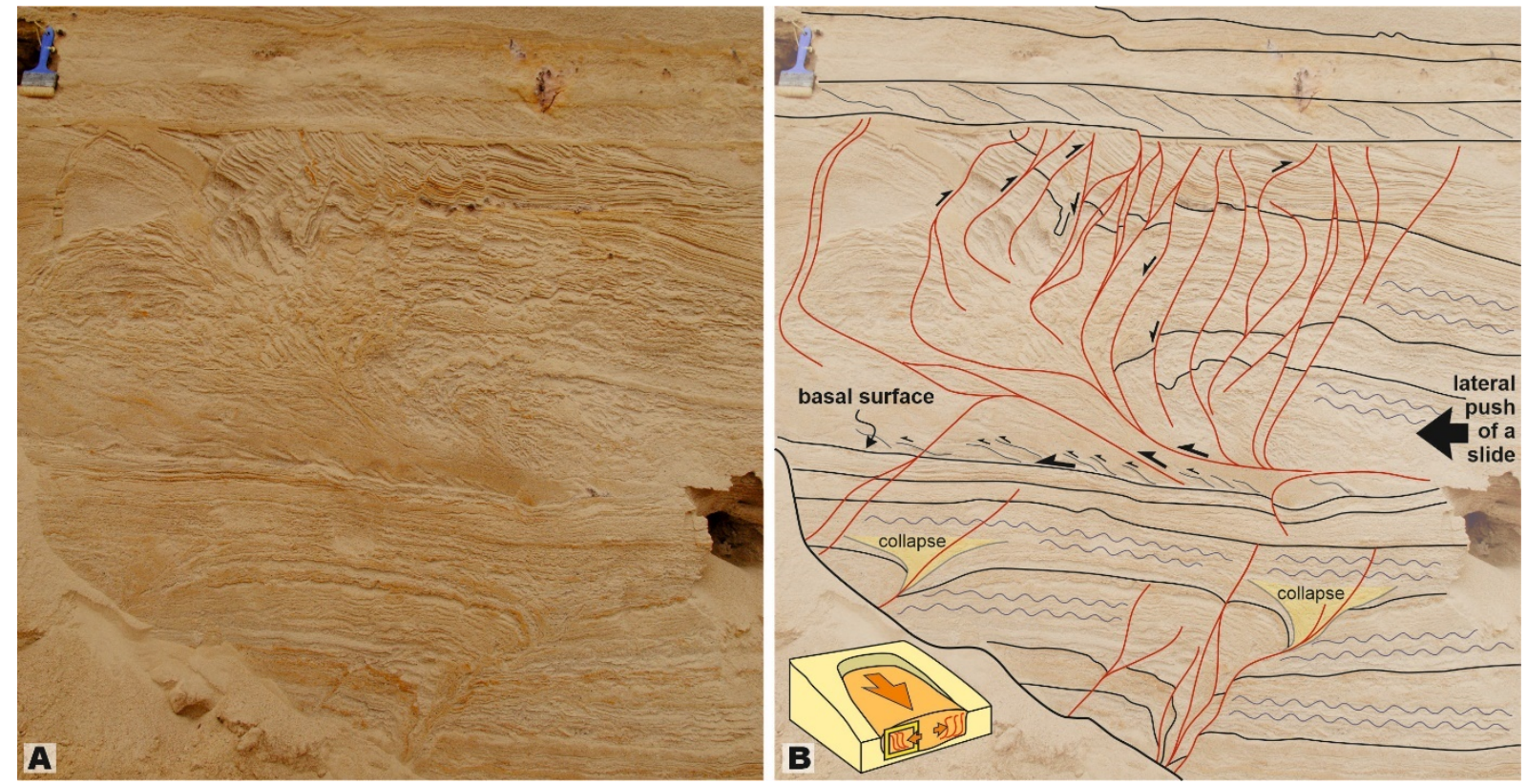

Fig. 13. A complex deformation, interpreted to be a result of compression in the marginal part of a slide

A large and complex deformation structure was observed in the left part of the upper level of the main wall (Fig. 7, Fig. 13). The whole deformed horizon is ca. $85 \mathrm{~cm}$ thick. It lies above horizontal sand beds crosscut by two wedges, but its internal deformations are not connected to the underlying fractures. The deformed body has numerous subvertical curved fractures, some of them with displacement (small faults), separating the sediment into blocks. A transition from normal slip along the faults to thrusting could be seen from the right towards the left (Fig. 13). Subvertical curved fractures continue to occur towards the left side with decreasing offset. The body does not exhibit significant deformation more to the right of the described complex deformation (Fig. 7). The basal detachment surface is marked by numerous centimeter scale thrusts oriented towards the left part of the outcrop (Fig. 13).

\subsection{Luminescence dating}

The natural OSL signals indicated relatively bright luminescence and fast OSL decay (Fig. 14A). The natural equivalent doses $\left(\mathrm{D}_{\mathrm{e}}\right)$ of the samples lay in the fast-growing region of the dose response curves (Fig. 14B). These are beneficial for OSL dating. 

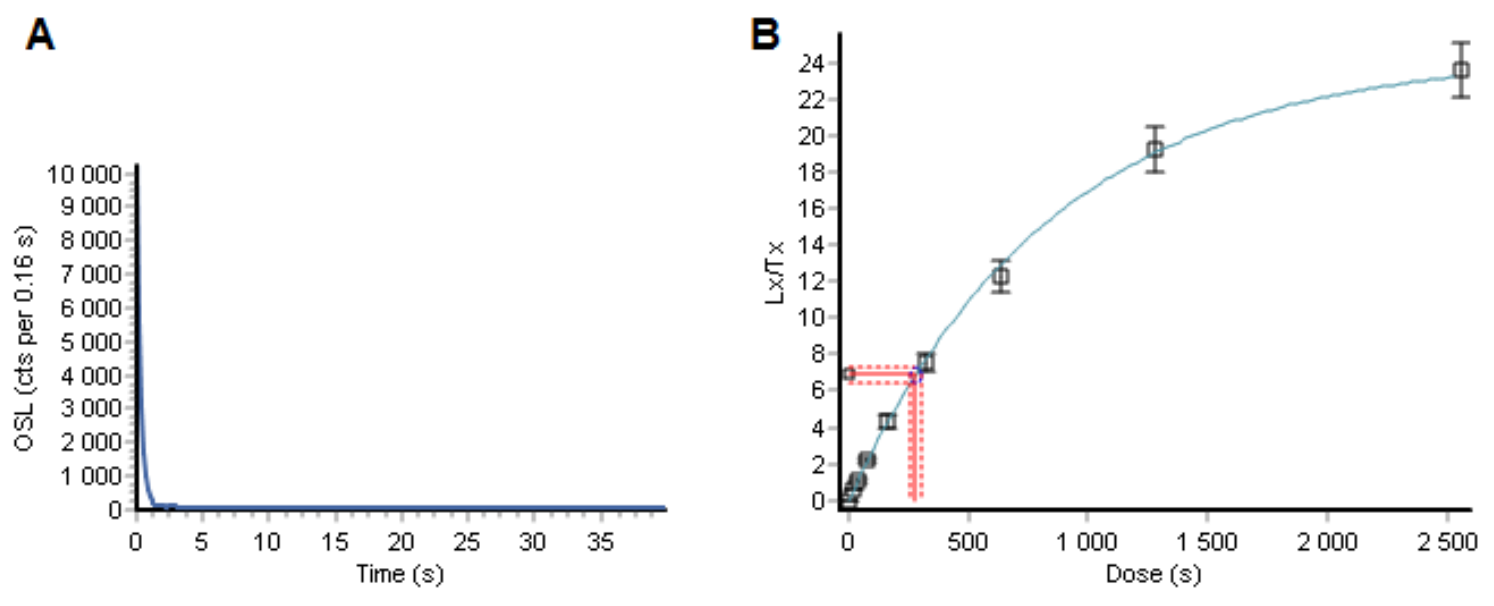

Fig. 14. Typical natural OSL signal or decay curve (A) and OSL dose response curve (B) of the quartz fractions on the examples of sample PS3. A dose of $2500 \mathrm{~s}$ corresponds to $226 \mathrm{~Gy}$.

Table 1. Dating results and overdispersion values (OD).

\begin{tabular}{|c|c|c|c|c|c|c|c|c|c|c|c|c|c|c|c|}
\hline \multirow{2}{*}{$\begin{array}{l}\text { Sample } \\
\text { PS1 }\end{array}$} & \multirow{2}{*}{$\begin{array}{c}\begin{array}{c}\text { Depth } \\
\text { (cm) }\end{array} \\
795\end{array}$} & \multirow{2}{*}{$\begin{array}{c}\mathbf{n} \\
30\end{array}$} & \multicolumn{4}{|c|}{$\begin{array}{c}\text { Equivalent dose } \\
\text { (Gy) }\end{array}$} & \multicolumn{3}{|c|}{ OD (\%) } & \multicolumn{3}{|c|}{$\begin{array}{l}\text { Dose rate } \\
\text { (Gy/ka) }\end{array}$} & \multicolumn{3}{|c|}{$\begin{array}{c}\text { OSL age } \\
\text { (ka) }\end{array}$} \\
\hline & & & 33,56 & \pm & 1,98 & median & & \pm & & 1,30 & \pm & 0,03 & 25,8 & \pm & 1,7 \\
\hline PS2 & 755 & 51 & 28,39 & & 1,35 & mean & & & & 1,42 & & 0,03 & 19,9 & \pm & 1,1 \\
\hline PS3 & 604 & 29 & 27,96 & 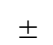 & 1,79 & med & 40 & \pm & 5 & 1,51 & 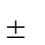 & 0,03 & 18,5 & \pm & 1,3 \\
\hline PS4 & 454 & 29 & 23,58 & \pm & 0,60 & mean & 13 & 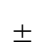 & 2 & 1,35 & \pm & 0,03 & 17,5 & \pm & $\mathbf{0 , 7}$ \\
\hline PS5 & 317 & 29 & 23,92 & \pm & 0,82 & mean & 17 & \pm & 2 & 1,36 & \pm & 0,03 & 17,6 & \pm & 0,8 \\
\hline PS6 & 274 & 55 & 23,56 & \pm & 0,64 & median & 17 & \pm & 2 & 1,37 & \pm & 0,03 & 17,2 & \pm & 0,7 \\
\hline PS7 & 172 & 36 & 22,69 & \pm & 1,07 & median & 22 & \pm & 3 & 1,36 & \pm & 0,03 & 16,7 & \pm & 0,9 \\
\hline
\end{tabular}

The equivalent doses are between 11 and 53 Gy. The distribution of the equivalent doses of each sample is more or less symmetric (except sample PS3), indicating that they belong to one population on the basis of the histograms and kernel density estimate curves of the abanico plots (Fig. 15) (Dietze et al., 2016). OSL dating is based on equivalent doses of 29-55 aliquots per sample (Table 1). More than fifty aliquots were measured in the case of samples PS2 and PS6 to obtain a more symmetric equivalent dose distribution. The ages were calculated with the mean or median $\mathrm{D}_{\mathrm{e}} \mathrm{-S}$, depending on which fit better to the peak area of the distribution. The overdispersion (OD) of the equivalent doses varies between 13 and $40 \%$ (Table 1). The sediments in the upper part of the section (sample PS4-7) with lower OD values were probably well bleached at the time of deposition, as laid down in Olley et al. (2004), or better bleached than the samples in the lower part of the section. 

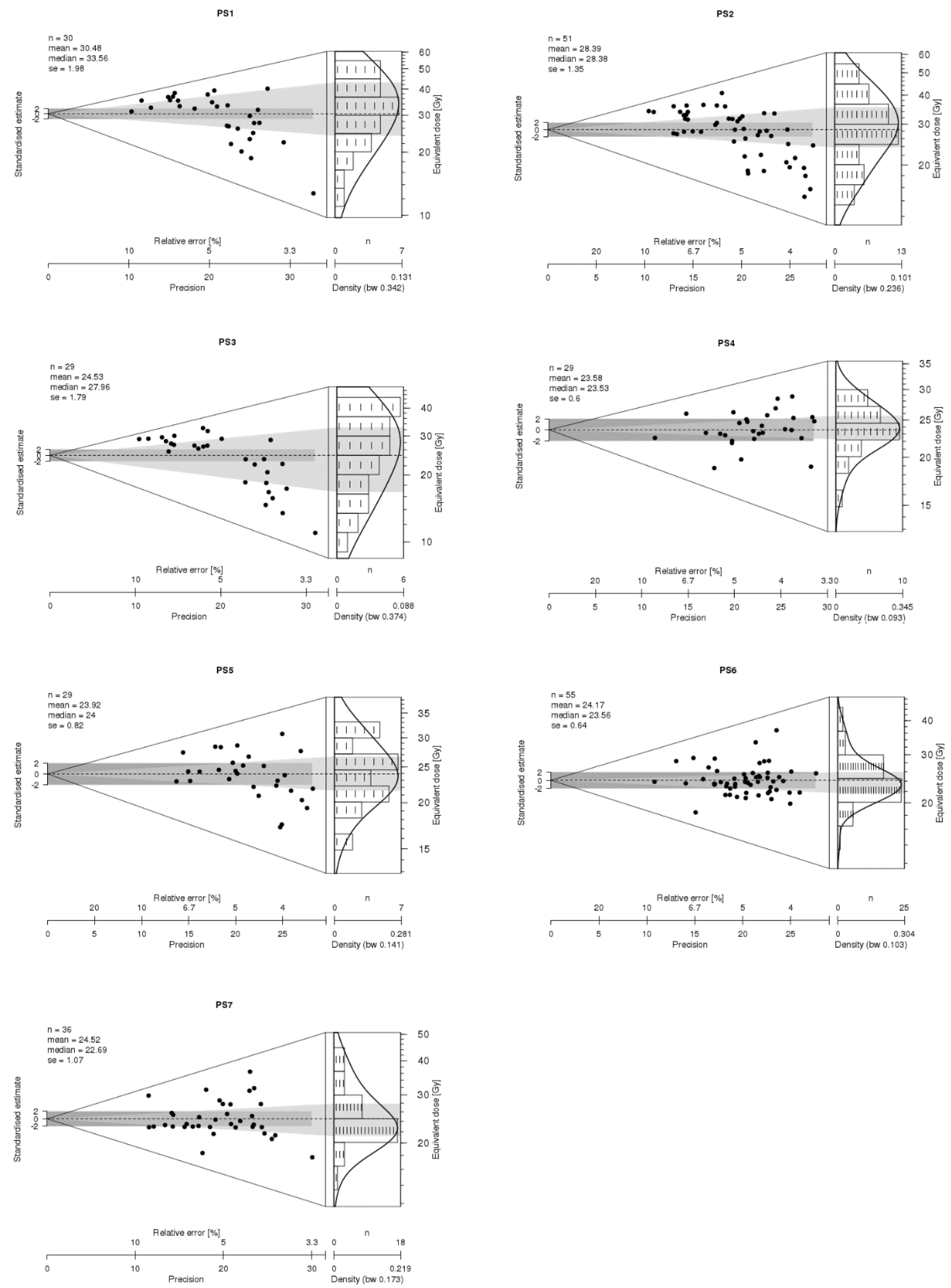

Fig. 15. Distributions and characteristics of the equivalent doses in abanico plots (R.Luminescence project, 2021).

The environmental dose rates were calculated on the basis of laboratory high-resolution gamma spectrometry measurements using a Canberra GC3020 on 1.0-1.1 kg bulk samples collected in the proximity of each OSL sample. Table 2 shows the resulting $\mathrm{U}$, Th and $\mathrm{K}$ concentrations. Dose rate conversion factors given by Guérin et al. (2011) were employed. The cosmic dose 
rates were determined according to the method set out in Prescott and Stephan (1982) and Prescott and Hutton (1994). The estimated average water content throughout the burial period of the dated eolian sediments was $11 \pm 2 \%$ according to the results of water content measurements on sediments taken from each OSL sampling tube, and after they were saturated by water in a laboratory.

Table 2. Results of gamma spectrometry measurements.

\begin{tabular}{|l|lll|lll|lll|}
\hline Sample & \multicolumn{2}{|c|}{ U (ppm) } & \multicolumn{2}{|c|}{ Th (ppm) } & \multicolumn{2}{|c|}{ K (\%) } \\
\hline PS1 & 0,54 & \pm & 0,01 & 1,85 & \pm & 0,05 & 1,13 & \pm & 0,01 \\
PS2 & 0,51 & \pm & 0,01 & $1,70 \pm$ & 0,05 & 1,28 & \pm & 0,01 \\
PS3 & 0,75 & \pm & 0,01 & 2,37 & \pm & 0,06 & 1,27 & \pm & 0,00 \\
PS4 & 0,50 & \pm & 0,01 & 1,66 & \pm & 0,05 & 1,16 & \pm & 0,01 \\
PS5 & 0,49 & \pm & 0,01 & 1,64 & \pm & 0,05 & 1,15 & \pm & 0,01 \\
PS6 & 0,52 & \pm & 0,01 & 1,68 & \pm & 0,05 & 1,15 & \pm & 0,01 \\
PS7 & 0,38 & \pm & 0,01 & 1,52 & \pm & 0,05 & 1,15 & \pm & 0,01 \\
\hline
\end{tabular}

The OSL ages range between $16.7 \pm 0.9 \mathrm{ka}$ and $25.9 \pm 1.7 \mathrm{ka}$ (Table 1 ). Within a reasonable margin of error, the ages are in stratigraphic order. This implies a relatively continuous deposition of sand in the area during the Last Glacial Maximum and during MIS2 (Clark et al., 2009).

The standard error $\sigma_{1}$ of the OSL ages in the range of $0.7-1.7 \mathrm{ka}$ is relatively high compared to the age range of the studied stratigraphic succession, reaching $9.2 \mathrm{kyr}$ between the mean ages. Hence, the Bayesian age-depth model was considered the most robust approach to the determination of the timing of depositional and deformation events. The resulting model in Fig. 16 displays linear trend, caused by the high degree of uncertainty concerning the ages in comparison to short period dated. The model fits well with samples PS2 to PS7, while the lowermost sample, PS1, lies at the very margin of acceptability, and might be considered as an outlier. Nevertheless, this lowermost sample might also represent a separate succession, comprising predominantly silty sands. The modeled age ranges within $\sigma_{1}$ error bars, median and mean ages in $1 \mathrm{~cm}$ steps are present in the Supplementary Table 1 for the depth range between dating samples. 

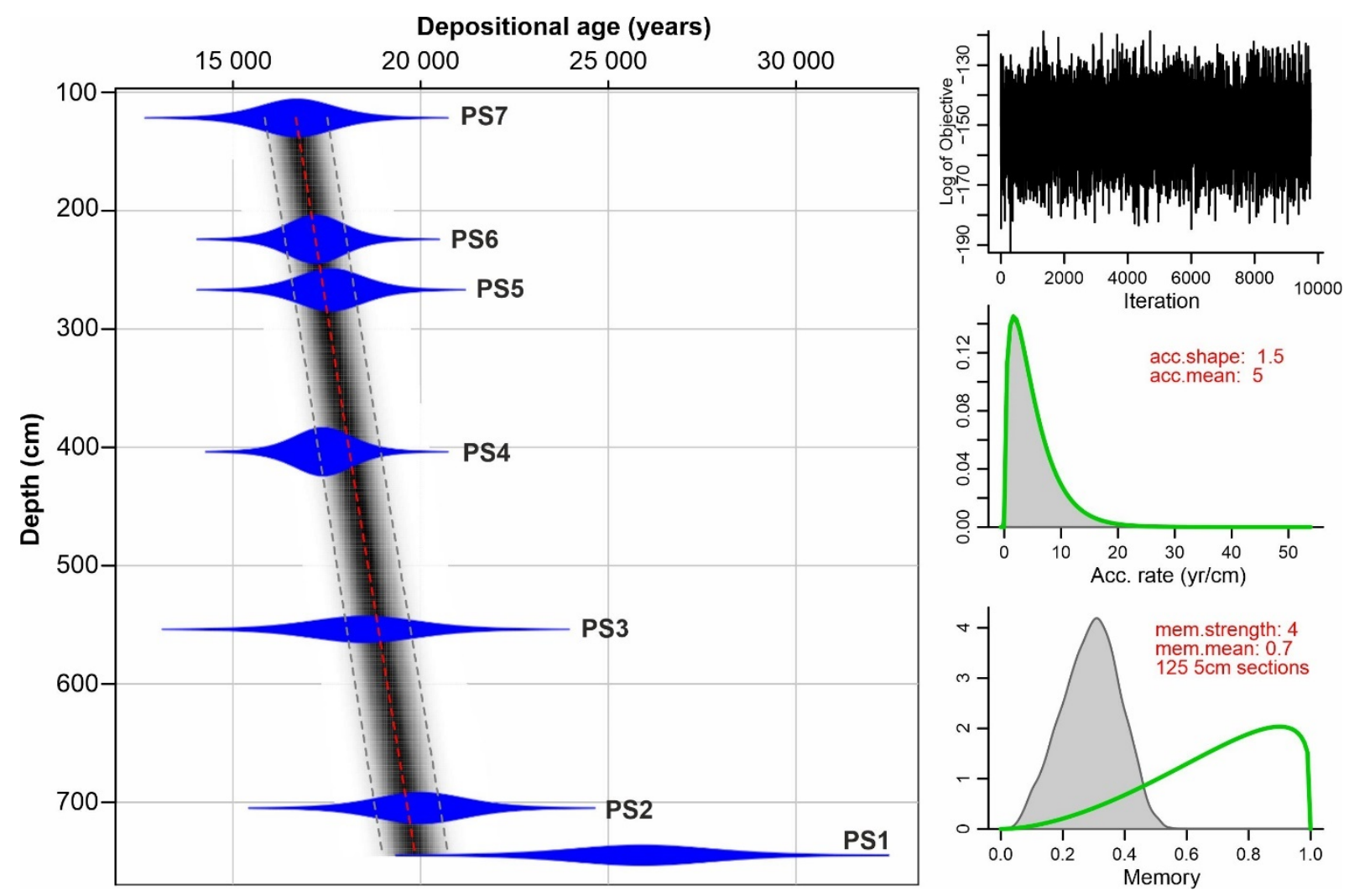

Fig. 16. Bacon age-depth model (Blaauw and Christen, 2011) applied to the OSL ages of the main wall outcrop in the Bažantnica sandpit. Grey dots indicate $95 \%$ probability intervals. The inset graphs show the number of MCMC iterations (upper), distributions of prior (green) and posterior (grey) accommodation rates (center) and memory of the modelling (lower). See Supplementary Table 1 for depicted age values of the dated samples.

\section{Origin of deformations}

\subsection{Mechanism of deformation}

The wedge-shaped deformations under consideration were first interpreted as water escape structures by Fordinál et al. (2012a) and Kadlec et al. (2015). However, the formation of water escape structures is a process characterized by an overall upward transport of the fluidized sandwater mixture (e.g., van Vliet-Lanoë et al., 2004; Owen et al., 2011). In contrast, the wedgeshaped structures here, as a general rule, are indicative of a downward transport of material. Moreover, water escape structures require sediment saturated with pore water. Bedding dips imply that the strata accumulated on a gently dipping slope of a sand sheet, and wedges formed at the surface, which was most probably within the vadose zone and not saturated by water.

The larger, vertical or subvertical wedges, where blocks of the original well-bedded sand were moving down, often along several planes at once, can be readily explained by the opening of extensional (dilation) cracks. However, many of the narrow fractures do not show any obvious downward movement of sand blocks, and they are quite strongly inclined (Fig. 8). As most of them display no displacement, they cannot be interpreted as faults running up to the surface. 
The downward bending of the marginal few centimeters of the sand layers could be explained by the lateral opening of the fracture, but in loose sands the overhanging side of the fracture should collapse immediately.

The rheology of loose sand can be significantly altered by frozen vadose water, though, and the strata can exhibit increased cohesion, both as has been shown experimentally and observed in clastic sediments in glacial and periglacial conditions (e.g., Steidtmann, 1973; Youssef and Hanna, 1988; Fitzsimons et al., 2001; Anderson et al., 2007; Waller et al., 2012; Kim et al., 2016; Fitzsimons and Howarth, 2020). According to the OSL dating results the depositional record in this case was formed during the cold MIS2, and within that, partly during the Last Glacial Maximum. The mean annual temperatures went as low as $0 \pm 2{ }^{\circ} \mathrm{C}$ and mean annual precipitation was estimated to attain only $30-50 \%$ of the present-day conditions for the lowland areas of the Pannonian Basin region during the time of deposition (Ruszkiczay-Rüdiger and Kern, 2016). Hence, the freezing of vadose water inside the sediment outcropping in the Bažantnica sandpit and increased cohesion of the strata may be considered a likely option.

The high degree of cohesion may also explain the formation of the layers with chaotic structure in otherwise loose sand. The original structure must have been disturbed by an abrupt trigger mechanism related to delivery of kinetic energy. Sharp contact of the disturbed horizons with the underlying undeformed beds implies that some rheological contrast might have existed in between. The fragmented structure with the fragmentary remains of the original bedding fits well to the expected increase of cohesion due to freezing of vadose pore water (Youssef and Hanna, 1988). The folded layers were probably formed by an analogous process, as they appear in comparable settings to the layers with chaotic structure, but with a different level of cohesion and higher degree of plasticity, likely due to their higher content of liquid water at the expense of ice content (Arenson et al., 2007). Folding is not uncommon in seismically deformed deposits (as reported in e.g., Taşgın et al., 2011; Liang et al., 2021, Sağlam Selçuk and Kul, 2021). A variety of cohesion settings might be expected in between the end members of loose sand and sand which is frozen solid.

The near-to-surface location of the deformations is indicated by the truncation of their uppermost parts in every documented case. On the other hand, the erosion was mostly gentle, since the overlying strata are generally conformable (Fig. 7). The erosion affected only few centimeters of the deformed surface, which was irregular due to the disturbance and folding of the uppermost layers as well as due to disruption by fractures and wedges. Eolian activity flattened the irregular sandy surface before the formation of new wind ripples. A significantly higher intensity of erosion produced major erosional surfaces, which truncated a significant part of the deformed horizons and led to angular bedding contacts.

The deformation in Fig. 13 does not penetrate below its $85 \mathrm{~cm}$ thickness, and pinches out towards the right side, while the body as a whole is delimited by a deformed basal surface; taken together, these imply the movement of a block of sediment as a mechanism of deformation. The observed deformation probably originated in the marginal part of a slide due 
to the pressure exerted towards the host sediment of the sand sheet, which is not exposed in the section under consideration (Fig. 13 - inserted block diagram). The sliding of eolian loose sand usually results in large (on the meter scale) massive, structureless bodies (Steidtmann, 1982; Loope et al., 1999; Ford et al., 2016). Nevertheless, the niveo-eolian depositional systems of cold regions often preserve slumped bedding in the depositional record (Koster and Dijkmans, 1988; Dijkmans, 1990). Hence, the freezing of sediment might allow the formation of a complex pattern of both brittle and ductile deformation meso-structures, which is much more common in heterolithic deposits than in granulometrically homogeneous sands (e.g., Alsop et al., 2016; 2017). The deformation seen in Fig. 13 displays a complex blocky pattern with a change from extensional to compressional regime within tens of centimeters horizontally, a feature frequently observed in slides (Alsop et al., 2020).

\subsection{Trigger of deformation}

The systematic orientation of fractures (Fig. 8) narrows the possible genetic explanations. In the case of eolian sands, bedding indicates the position of the paleosurface. The strike of the fractures is perpendicular to that of the gently dipping sand beds in the main wall and has no regularity in relation to the bedding observed in the remaining walls of the sandpit, therefore, the formation of the fractures by slope mass movement can be excluded. The inclination of the fractures (relatively large in relation to the vertical) and the uniform orientation of the fractures rules out a periglacial (frost or ice wedge) origin, as well.

Surface rupture by planar fractures is a common feature in seismically active areas with unconsolidated sediments. Fractures without vertical displacement, similar to those observed in the Bažantnica sandpit, are usually either dilation cracks or fractures acting as conduits for liquefied sediment to the surface. Both types form above blind faults (Alessio et al., 2012; Caputo et al., 2012; Moretti et al., 2014; Konrád et al., 2021) or as off-fault features in the vicinity of surface-rupturing faults (e.g., Philip and Meghraoui, 1983; Pollak et al., 2021). These ruptures are usually arranged systematically with respect to the orientation of the seismic wave, parallel with the $\sigma_{1}$ and perpendicular to the $\sigma_{3}$ stress axes (Burbank and Anderson, 2011). The movement of liquified sand upwards along fractures requires appropriate sediments - it is typical, for example, of alluvial successions - and an earthquake with a minimum magnitude of 5.5 (Guarnieri et al., 2009; Alessio et al., 2012; Amorosi et al., 2016). Structures related to water escape were not found in the sand pit examined here, implying that earthquake magnitudes within the area and time interval under investigation were below 5.5. It has been documented that liquefaction appears in eolian sands at the point of contact with water table (e.g., Chan et al., 2019; Espinoza et al., 2020; Rodríguez-López and Wu, 2020; Konrád et al. 2021). However, no study describing how frozen eolian sand behaves when experiencing a seismic shock could be found in the course of the research presented here.

A process-based model of the origin of the deformations described here is illustrated in Figs. 17 and 18. A significant number of the wedges are filled by the material of beds with chaotic fabric, implying that the soft-sediment deformation of these beds appears just before the 
formation of the wedges. Firstly, the seismic shock causes disturbance or folding of the uppermost layers of the eolian sediment (Fig. 17B). A fracture disrupts the surface of cohesive sand shortly after, and a collapse wedge forms, filled rapidly by the material of already disturbed topmost beds (Fig. 17C). The increased cohesion also allows formation of an overhanging side of an open rupture.
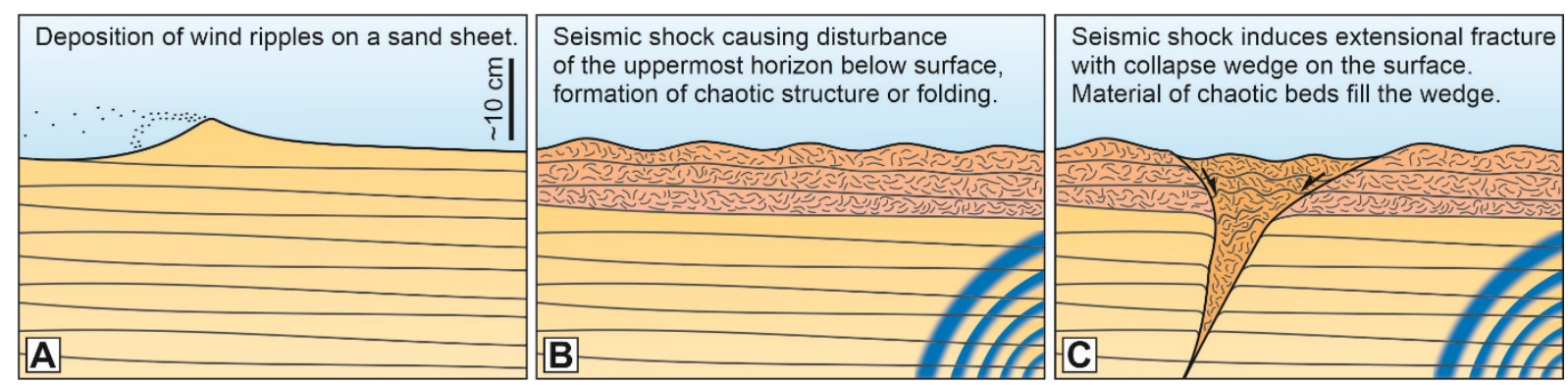

Fig. 17. A tentative model of surface deformation caused by a seismic shock in cohesive eolian sand. Stage C appears immediately after B during a single earthquake.

The continuous aggradation of the sand sheet allowed the recording of a number of successive deformation events (Fig. 18). The prevailing conformable contact of the strata overlying the deformed horizons was caused by the smooth beveling of the deformed surface (Fig. 18C). The repetition of earthquakes led to the successive formation of collapse wedges above the same fractures (Fig. 18D). The fractures were then reactivated, ceased to be active, or might have undergone splitting in more active fractures (Fig. 18G). The repeated formation of the wedges is related to the propagation of a fracture across the older wedges, which is expressed as planar inhomogeneity in the generally isotropic fill of a wedge (Fig. 9A,F). Major erosion events appeared less frequently and cut off the upper few tens of centimeters, including a major part of the deformed horizons (Fig. 18E). The slide deformation observed in the upper part of the main wall (Figs. 7,13 ) was most probably triggered by a seismic shock, in a way similar to other deformations. 


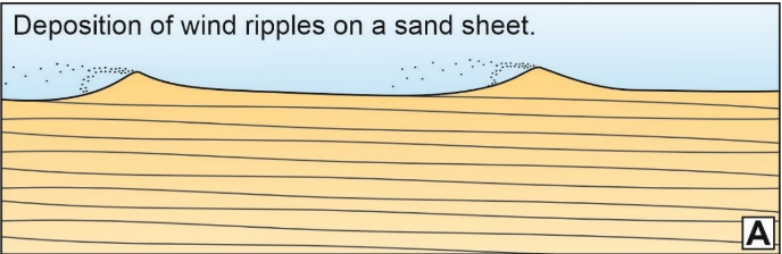

Seismic shock causes plastic deformation of subsurface horizon resulting in chaotic or folded structure. Formation of fractures, sand collapses into wedges near the surface.

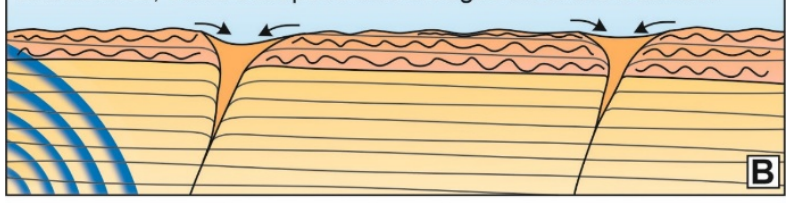

Erosion of uppermost few centimeters of the deformed horizon. Deposition of wind ripples on a sand sheet.

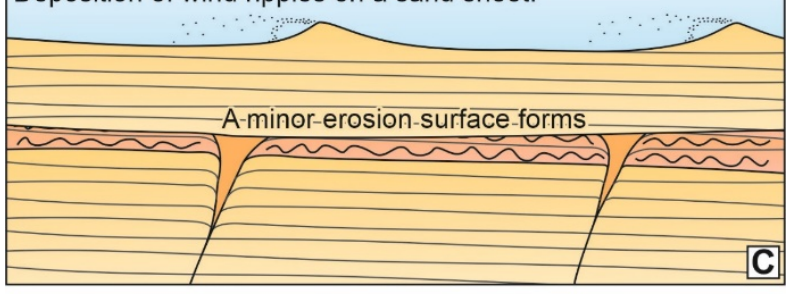

Seismic shock, successive growth of the sand wedges above the existing fractures, plastic deformation of topmost layers.
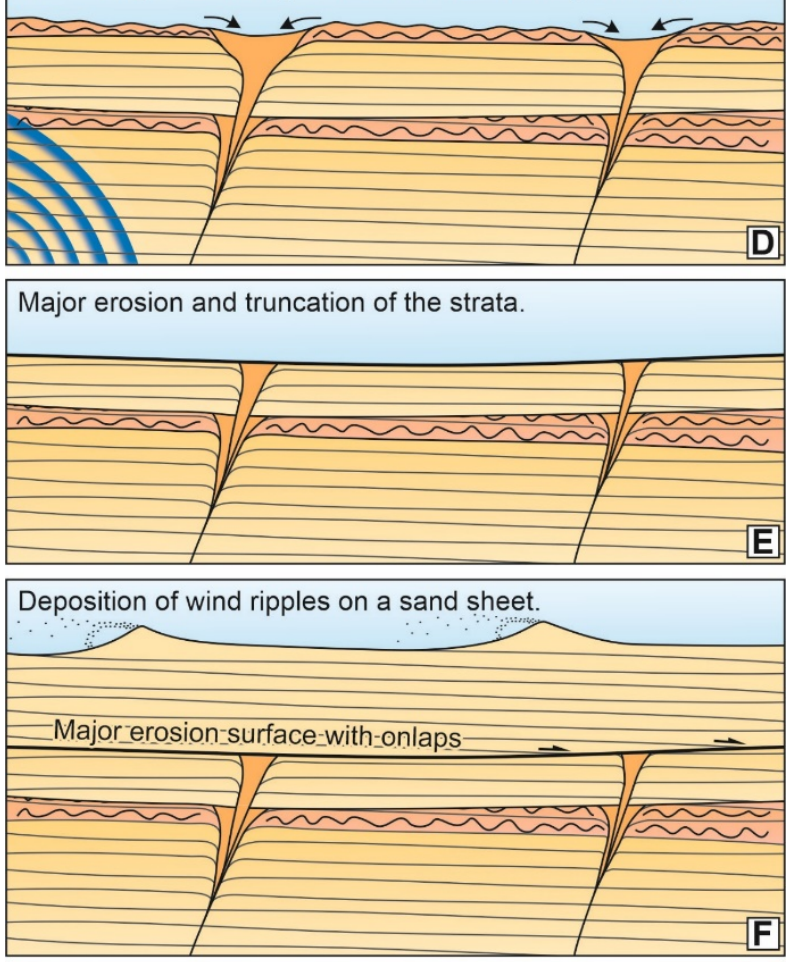

Seismic shock, cessation of activity of one fracture, branching of the second fracture into two collapse wedges, plastic def.

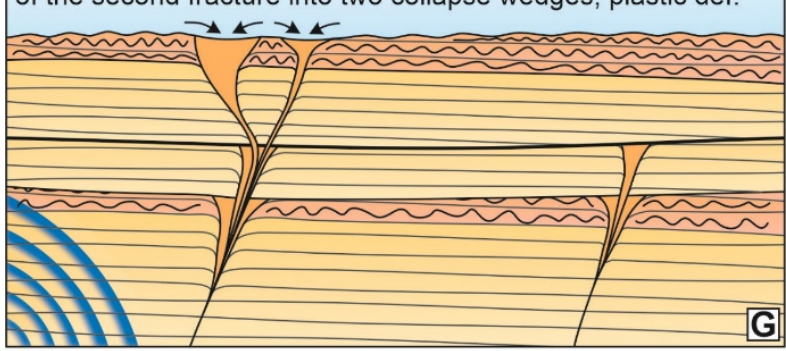

eolian ripples

sand and

granules

of a collapse deformed horizon wedge

Fig. 18. A tentative process-based model of the successive formation of the collapse sand wedges in response to seismic shock and rupture of the surface of frozen partly cohesive sand in an aggrading sand sheet. .

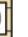

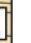




\subsection{Spatial relationship of observed deformations to the Vienna Basin Transfer Fault and the recent stress field}

Although the neotectonic kinematics of the VBTF in the Slovak part of the Vienna Basin was not investigated in detail, thorough analyses of reflection seismics, focal mechanisms, morphotectonic features and trenching resulted in an accepted kinematic model of the VBTF in the Austrian part of the basin, located ca. 20-40 km towards SW from the Bažantnica sandpit (e.g., Decker et al., 2005; Beidinger and Decker, 2011; Hinsch and Decker, 2011; Tary et al., 2015; Weissl et al., 2017; Hintersbergher et al., 2018). The VBTF displayed sinistral transtensional strike-slip kinematics with SW-NE trending of faults and prevailing W-E orientation of extension during the period of deposition of the succession in the Bažantnica sandpit (e.g., Decker et al., 2005). The dominant N-S orientation of documented fractures (Fig. 8) is consistent with the suggested stress field and agrees with their interpretation of it having been formed by seismic events originating in the activity of the VBTF.

\section{Earthquake recurrence periods}

The linear Bacon age-depth model yielded an accumulation rate of $0.196 \mathrm{~cm} / y e a r$ for the main wall outcrop of the Bažantnica sandpit (Fig. 16). Examples of accumulation rates of sand sheets based on geochronology vary significantly worldwide, with values ranging from $0.0067-0.094$ cm/year (Hall et al., 2010), through 0.01-0.02 cm/year (Ward et al., 2005), 0.013-0.09 cm/year (Hall et al., 2011), 0.018-0.49 cm/ka (Morrocco et al., 2007), up to 1-12 cm/year (Stokes et al., 1998). Hence, the obtained accumulation rate falls within a reasonable range.

The deformations described herein are considered to have been formed by a seismic shock. Hence, their repeated occurrence in a vertical succession allows for the determination of recurrence periods of earthquake events. The wedges deforming a single horizon are treated as the result of a single event. The number of distinct deformation events on the main wall is 21 (Suppl. Table 2).

The Bacon age-depth model-based age ranges and mean ages were lined up against the depths of deformed horizons and are included in Supplementary Table 2. Since the age error bars of the age-depth model are related to the error bars of the OSL ages, they reach relatively high values with a mean $\sigma_{1}=837.44 \mathrm{ka}$ (Suppl. Table 1 ). Therefore, the ages of deformation events do exhibit error bars significantly exceeding the time span between most of the events (Fig. 19A).

The obtained distribution of mean ages of deformation events allows the determination of the recurrence periods of these events (Fig. 19B). It is important to mention that this calculation is biased by the much lower number of dating results in comparison to the number of interpreted events. However, a higher number of OSL ages would most probably not decrease the standard deviations of the age-depth model, as this is mainly related to the ratio between dating error bars and the depositional time span of the succession. 


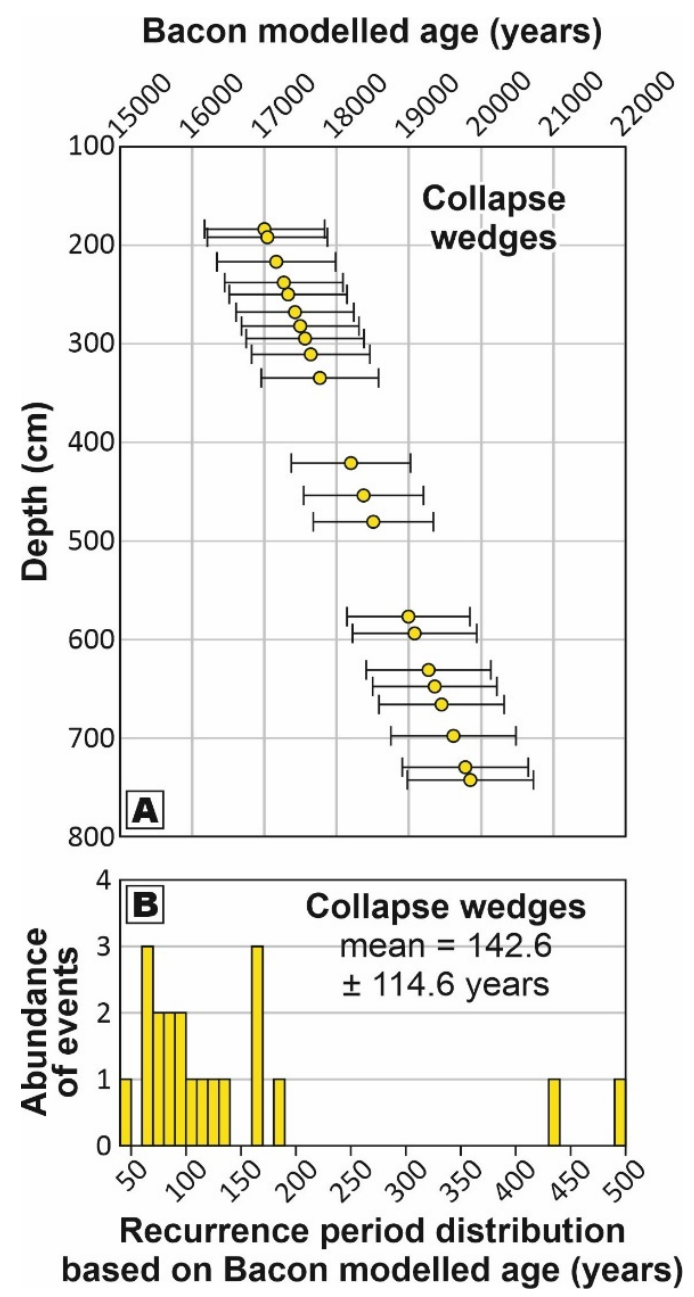

Fig. 19. Ages of the deformations based on the Bacon age-depth model (A) and histogram of the recurrence period distribution (B). All uncertainties are $\sigma 1$. Standard deviation of mean values in B considers only the distribution of time intervals between the events and does not include dating uncertainty. See Supplementary Table 2 for depicted values.

The mean age distribution of collapse wedges shows a relatively uniform pattern in the lower and upper portions of the section, while the central part contains only three events separated by periods of 435 and 492 years, respectively (Fig. 19A). The upper time gap without collapse wedges is fully exposed in the outcrop, therefore it represents a real quiescence of fault activity. The lower gap is partly covered, and it is possible that a few deformation events might have gone unnoticed in this interval. The recurrence period of deformation events is generally between 40 and 190 years, with a mean value of $142.6 \pm 114.6$ years (Fig. 19B).

\section{Conclusions}

This study yielded a detailed analysis of soft-sediment deformation structures (SSDS) present in outcrops of an Upper Pleistocene eolian sand sheet in the eastern Vienna Basin, Central Europe. Sedimentological study was combined with dating using optically stimulated luminescence. The observed deformations include collapse wedges, beds with chaotically disturbed horizons, folded beds and sliding. The mechanism of deformation implies some 
cohesion of the deformed strata, which is attributed to seasonal frost and the presence of vadose water within the sediment.

The systematic orientation of fractures, their joint presence in specific horizons together with chaotic and folded beds, and the location of the study area on an active Quaternary fault system suggest that the deformations were triggered by repeated seismic shocks. The age distribution of the deformation events based on the Bayesian age-depth model yielded a recurrence period of $142.6 \pm 114.6$ years. The recurrence period calculation is biased with a relatively high standard deviation of the age-depth model, associated with the high ratio between OSL uncertainties and the duration of dated period, but it does nonetheless give an order of magnitude for the recurrence times.

The formation of SSDS in eolian sands under cold climates is rare and needs to be examined in more detailed studies of periglacial successions elsewhere. Modeling under laboratory conditions is needed to confirm the process-based interpretation of the origin of deformation structures presented here. The findings of present study imply that collapse wedges, chaotically disturbed and folded beds are important proxies for paleoseismic activity, and their recognition will help to identify past earthquakes in the depositional record. An unexpected potential of periglacial eolian deposits to record seismic events is another noteworthy piece of information provided by the study.

\section{Acknowledgements}

The study was supported by the Slovak Research and Development Agency (APVV) under contract No. APVV-15-0575, APVV-16-0121, APVV-20-0120 and SK-HU-2013-0020. Nafta a.s. and the Geofond archive of the State Geological Survey of Dionýz Štúr are thanked for allowance to publish the reflection seismic section. Katarína Lacová (Military Forests and Estates of the SR, SOE), Peter Hiadlovský (Ministry of Defense SR, Office of Process Management, Organization and Specialized State Administration), Ján Karovič (SAZAN, ltd.) and the Military district of Záhorie (Malacky) are thanked for kind allowance to perform the research in the Bažantnica sandpit. Thanks to Ágnes Novothny (Eötvös Loránd University, Budapest) for the help in OSL measurements, to the colleagues in the Mining and Geological Survey of Hungary: Attila Nagy for gamma spectrometry measurements, Miklósné Bátori and Judit Füri for sample preparation, and Zsolt Horváth for water content determination. Martin Mal'a is thanked for consultation of rheology of frozen sediment. The borehole profiles on Fig. 4 were acquired in the Geofond archive of the State Geological Survey of Dionýz Štúr, Bratislava (Slovakia). The free availability of the Lidar DEM data from the Geodesy, Cartography and Cadastre Authority of the Slovak Republic is acknowledged with gratitude. Paul Thatcher is thanked for his efforts made during the language correction. 


\section{References}

Alessio, G., Alessio, G., Alfonsi, L., Brunori, C.A., Burrato, P., Casula, G., Cinti, F., Civico, R., Colini, L., Cucci, L., De Martini, P.M., Falcucci, E., Galadini, F., Gaudiosi, G., Gori, S., Mariucci, M., Montone, P., Moro, M., Nappi, R., Villani, F., 2012. A photographic dataset of the coseismic geological effects induced on the environment by the 2012 Emilia (northern Italy) earthquake sequence, 16.

Alsop, G.I., Marco, S., Weinberger, R., Levi, T., 2016. Sedimentary and structural controls on seismogenic slumping within mass transport deposits from the Dead Sea Basin. Sedimentary Geology 344, 71-90.

Alsop, G.I., Marco, S., Weinberger, R., Levi, T., 2017. Upslope-verging back thrusts developed during downslope-directed slumping of mass transport deposits. Journal of Structural Geology 100, 45-61.

Alsop, G.I., Weinberger, R., Marco, S., Levi, T., 2020. Distinguishing coeval patterns of contraction and collapse around flow lobes in mass transport deposits. Journal of Structural Geology 134, 104013.

Amorosi, A., Bruno, L., Facciorusso, J., Piccin, A., Sammartino, I., 2016. Stratigraphic control on earthquake-induced liquefaction: A case study from the Central Po Plain (Italy). Sedimentary Geology 345, 42-53.

Ansberque, C., Bellier, O., Godard, V., Lasserre, C., Wang, M., Braucher, R., Talon, B., De Sigoyer, J., Xu, X., Bourlès, D.L., 2016. The Longriqu fault zone, eastern Tibetan Plateau: Segmentation and Holocene behavior. Tectonics 35, 565-585.

Arenson, L.U., Springman, S.M., Sego, D.C., 2007. The rheology of frozen soils. Applied Rheology 17, 12147-12141.

Balázs, A., Magyar, I., Matenco, L., Sztanó, O., Tökés, L., Horváth, F., 2018. Morphology of a large paleo-lake: Analysis of compaction in the Miocene-Quaternary Pannonian Basin. Global and Planetary Change 171, 134-147.

Beidinger, A., Decker, K., 2011. 3D geometry and kinematics of the Lassee flower structure: Implications for segmentation and seismotectonics of the Vienna Basin strike-slip fault, Austria. Tectonophysics 499, 22-40.

Beidinger, A., Decker, K., Roch, K.H., 2011. The Lassee segment of the Vienna Basin fault system as a potential source of the earthquake of Carnuntum in the fourth century a.d. International Journal of Earth Sciences 100, 1315-1329.

Benedetti, L., Finkel, R., King, G., Armijo, R., Papanastassiou, D., Ryerson, F.J., Flerit, F., Farber, D., Stavrakakis, G., 2003. Motion on the Kaparelli fault (Greece) prior to the 1981 earthquake sequence determined from ${ }^{36} \mathrm{Cl}$ cosmogenic dating. Terra Nova 15, 118-124.

Bielik, M., Kováč, M., Kučera, I., Michalík, P., Šujan, M., Hók, J., 2002. Neo-alpine linear density boundaries (faults) detected by gravimentry. Geologica Carpathica 53, 235-244.

Blaauw, M., Christen, J., 2011. Flexible paleoclimate age-depth models using an autoregressive gamma process. Bayesian Analysis 6, 457-474.

Bryant, G., Cushman, R., Nick, K., Miall, A., 2016. Paleohydrologic controls on soft-sediment deformation in the Navajo Sandstone. Sedimentary Geology 344, 205-221.

Burbank, D.W., Anderson, R.S., 2011. Tectonic Geomorphology: Second Edition. Tectonic Geomorphology: Second Edition, 460 pp.

Caputo, R., Iordanidou, K., Minarelli, L., Papathanassiou, G., Poli, M.E., Rapti-Caputo, D., Sboras, S., Stefani, M., Zanferrari, A., 2012. Geological evidence of pre-2012 seismic events, Emilia-Romagna, Italy. Annals of Geophysics 55, 743-749.

Caputo, R., Poli, M.E., Minarelli, L., Rapti, D., Sboras, S., Stefani, M., Zanferrari, A., 2016. Palaeoseismological evidence for the 1570 Ferrara earthquake, Italy. Tectonics 35, 14231445. 
Carcaillet, J., Manighetti, I., Chauvel, C., Schlagenhauf, A., Nicole, J.-M., 2008. Identifying past earthquakes on an active normal fault (Magnola, Italy) from the chemical analysis of its exhumed carbonate fault plane. Earth and Planetary Science Letters 271, 145-158.

Clark, P.U., Dyke, A.S., Shakun, J.D., Carlson, A.E., Clark, J., Wohlfarth, B., Mitrovica, J.X., Hostetler, S.W., McCabe, A.M., 2009. The Last Glacial Maximum. Science 325, 710714.

Cojan, I., Thiry, M., 1992. Seismically induced deformation structures in Oligocene shallowmarine and aeolian coastal sands (Paris Basin). Tectonophysics 206, 79-89.

Cunningham, A.C., Wallinga, J., 2010. Selection of integration time intervals for quartz OSL decay curves. Quaternary Geochronology 5, 657-666.

Decker, K., 1996. Miocene tectonics at the Alpine-Carpathian junction and the evolution of the Vienna Basin. Mitteilungen der Gesellschaft der Geologie- und Bergbaustudenten in Osterreich 41, 33-44.

Decker, K., Peresson, H., Hinsch, R., 2005. Active tectonics and Quaternary basin formation along the Vienna Basin Transform fault. Quaternary Science Reviews 24, 305-320.

Dietze, M., Kreutzer, S., Burow, C., Fuchs, M.C., Fischer, M., Schmidt, C., 2016. The abanico plot: Visualising chronometric data with individual standard errors. Quaternary Geochronology 31, 12-18.

Dijkmans, J.W.A., 1990. Niveo-aeolian sedimentation and resulting sedimentary structures; søndre strømfjord area, Western Greenland. Permafrost and Periglacial Processes 1, 8396.

Enzel, Y., Kadan, G., Eyal, Y., 2000. Holocene Earthquakes Inferred from a Fan-Delta Sequence in the Dead Sea Graben. Quaternary Research 53, 34-48.

Espinoza, N., Melchor, R.N., del Papa, C., 2020. Sand pipes in eolian deposits as recorders of Andean deformation in the Miocene Angastaco Formation, northwest Argentina. Journal of South American Earth Sciences 103, 102730.

Fitzsimons, S., Howarth, J., 2020. Development of push moraines in deeply frozen sediment adjacent to a cold-based glacier in the McMurdo Dry Valleys, Antarctica. Earth Surface Processes and Landforms 45, 622-637.

Fitzsimons, S.J., McManus, K.J., Sirota, P., Lorrain, R.D., 2001. Direct shear tests of materials from a cold glacier: implications for landform development. Quaternary International 86, 129-137.

Fodor, L., 1995. From transpression to transtension: Oligocene-Miocene structural evolution of the Vienna basin and the East Alpine-Western Carpathian junction. Tectonophysics 242, 151-182.

Fodor, L., Bada, G., Csillag, G., Horváth, E., Ruszkiczay-Rüdiger, Z., Palotás, K., Síkhegyi, F., Timár, G., Cloetingh, S., Horváth, F., 2005. An outline of neotectonic structures and morphotectonics of the western and central Pannonian Basin. Tectonophysics 410, 15-41.

Ford, C., Bryant, G., Nick, K.E., 2016. Architectural evidence of dune collapse in the Navajo Sandstone, Zion National Park, Utah. Sedimentary Geology 344, 222-236.

Fordinál, K., Maglay, J., Elečko, A., Nagy, A., Moravcová, M., Vlačiky, M., Kohút, M., Németh, Z., Bezák, V., Plašienka, D., Olšavský, M., Polák, M., Havrila, M., Hók, J., Kucharič, L., Kubeš, P., Malík, P., Liščák, P., Baláž, P., Madarás, J., Šefč́́k, P., Baráth, I., Boorová, D., Zlinská, A., Žecová, K., Pešková, I., 2012a. Explanatory notes to the geological map of the Záhorská Nížina Lowland, scale 1 : 50 000, ISBN 978-80-8934370-6. State Geological Survey of Dionýz Štúr and Ministry of the Environment of the Slovak Republic, Bratislava, Slovakia.

Fordinál, K., Maglay, J., Elečko, A., Nagy, A., Moravcová, M., Vlačiky, M., Kučera, M., Polák, M., Plašienka, D., Filo, I., Olšavský, M., Buček, S., Havrila, M., Kohút, M., Bezák, V., Németh, Z., 2012b. Geological map of the Záhorská Nížina Lowland, scale 1 : 50000. 
State Geological Survey of Dionýz Štúr and Ministry of the Environment of the Slovak Republic, Bratislava, Slovakia, http://apl.geology.sk/gm50js/.

Fryberger, S.G., Hesp, P., Hastings, K., 1992. Aeolian granule ripple deposits, Namibia. Sedimentology 39, 319-331.

Gribovszki, K., Kovács, K., Mónus, P., Bokelmann, G., Konecny, P., Lednická, M., Moseley, G., Spötl, C., Edwards, R.L., Bednárik, M., Brimich, L., Tóth, L., 2017. Estimating the upper limit of prehistoric peak ground acceleration using an in situ, intact and vulnerable stalagmite from Plavecká priepast cave (Detrekői-zsomboly), Little Carpathians, Slovakia-first results. Journal of Seismology 21, 1111-1130.

Guarnieri, P., Pirrotta, C., Barbano, M.S., De Martini, P.M., Pantosti, D., Gerardi, F., Smedile, A., 2009. Paleoseismic investigation of historical liquefactions along the Ionian coast of sicily. Journal of Earthquake Engineering 13, 68-79.

Guérin, G., Mercier, N., Adamiec, G., 2011. Dose-rate conversion factors: update. Ancient TL 29, 5-8.

Hall, S.A., Goble, R.J., 2011. New optical age of the Mescalero sand sheet, southeastern New Mexico. New Mexico Geology 33, 9-16.

Hall, S. A., Miller, M. R., and Goble, R. J., 2010. Geochronology of the Bolson sand sheet, New Mexico and Texas, and its archaeological significance: Geological Society of America Bulletin 122, 1950-1967.

Harzhauser, M., Daxner-Hock, G., Piller, E.W., 2004. An integrated stratigraphy of the Pannonian (Late Miocene) in the Vienna Basin. Austrian Journal of Earth Sciences 9596, 6-19.

Hinsch, R., Decker, K., 2003. Do seismic slip deficits indicate un underestimated earthquake potential along the Vienna Basin transfer fault system? Terra Nova 15, 343-349.

Hinsch, R., Decker, K., 2011. Seismic slip rates, potential subsurface rupture areas and seismic potential of the Vienna Basin Transfer Fault. International Journal of Earth Sciences 100, 1925-1935.

Hinsch, R., Decker, K., Wagreich, M., 2005. 3-D mapping of segmented active faults in the southern Vienna Basin. Quaternary Science Reviews 24, 321-336.

Hintersberger, E., 2012. Establishing a paleo-earthquake record in the Vienna Basin (Austria) using luminescence dating. Quaternary International 279-280, 201.

Hintersberger, E., Decker, K., Lomax, J., Lüthgens, C., 2018. Implications from palaeoseismological investigations at the Markgrafneusiedl Fault (Vienna Basin, Austria) for seismic hazard assessment. Natural Hazards and Earth System Sciences 18, 531-553.

Hók, J., Kováč, M., Pelech, O., Pešková, I., Vojtko, R., Králiková, S., 2016a. The Alpine tectonic evolution of the Danube Basin and its northern periphery (southwestern Slovakia). Geologica Carpathica 67, 495-505.

Hók, J., Kysel, R., Kováč, M., Moczo, P., Kristek, J., Kristeková, M., Šujan, M., 2016b. A seismic source zone model for the seismic hazard assessment of Slovakia. Geologica Carpathica 67, 273-288.

Hölzel, M., Decker, K., Zámolyi, A., Strauss, P., Wagreich, M., 2010. Lower Miocene structural evolution of the central Vienna Basin (Austria). Marine and Petroleum Geology 27, 666-681.

Holzer, T.L., Noce, T.E., Bennett, M.J., 2015. Strong ground motion inferred from liquefaction caused by the 1811-1812 New Madrid, Missouri, earthquakes. Bulletin of the Seismological Society of America 105, 2589-2603.

Horváth, F., Bada, G., Szafián, P., Tari, G., Ádám, A., Cloetingh, S., 2006. Formation and deformation of the Pannonian Basin: Constraints from observational data, Geological Society Memoir, pp. 191-206. 
Hughes, P.D., Gibbard, P.L., 2015. A stratigraphical basis for the Last Glacial Maximum (LGM). Quaternary International 383, 174-185.

Hunter, R.E., 1977. Basic types of stratification in small eolian dunes. Sedimentology 24, 361387.

Hurst, A., Glennie, K.W., 2008. Mass-wasting of ancient aeolian dunes and sand fluidization during a period of global warming and inferred brief high precipitation: The Hopeman Sandstone (late Permian), Scotland. Terra Nova 20, 274-279.

Chan, M.A., Bruhn, R.L., 2014. Dynamic liquefaction of Jurassic sand dunes: processes, Origins, and implications. Earth Surface Processes and Landforms 39, 1478-1491.

Chan, M.A., Hasiotis, S.T., Parrish, J.T., 2019. Enigmatic clastic pipe swarms and implications for fluidization dynamics in aeolian deposits. Sedimentology 66, 513-535.

Jackson, N.L., Nordstrom, K.F., 1998. Aeolian transport of sediment on a beach during and after rainfall, Wildwood, NJ, USA. Geomorphology 22, 151-157.

Jordan, O.D., Mountney, N.P., 2010. Styles of interaction between aeolian, fluvial and shallow marine environments in the Pennsylvanian to Permian lower Cutler beds, south-east Utah, USA. Sedimentology 57, 1357-1385.

Kadlec, J., Kocurek, G., Mohrig, D., Shinde, D.P., Murari, M.K., Varma, V., Stehlík, F., Beneš, V., Singhvi, A.K., 2015. Response of fluvial, aeolian, and lacustrine systems to late Pleistocene to Holocene climate change, Lower Moravian Basin, Czech Republic. Geomorphology 232, 193-208.

Kim, S.Y., Hong, W.T., Lee, J.S., Kim, Y., Strength assessment of frozen soils by instrumented dynamic cone penetrometer. In, Proceedings of the $5^{\text {th }}$ International Conference on Geotechnical and Geophysical Site Characterisation, ISC 2016. 2016, pp. 329-332.

Konrád, Gy., Sebe, K., Halász, A., 2021. Késő negyedidőszaki szeizmikus aktivitás nyomai futóhomokban, a Dunaszentgyörgy-Hartai-vetözónában (Traces of late Quaternary seismic activity in aeolian sand in the Dunaszentgyörgy-Harta Fault Zone, Hungary). Földtani Közlöny 151, 179-200. DOI: 10.23928/foldt.kozl.2021.151.2.179

Koster, E.A., Dijkmans, J.W.A., 1988. Niveo-aeolian deposits and denivation forms, with special reference to the great Kobuk Sand Dunes, Northwestern Alaska. Earth Surface Processes and Landforms 13, 153-170.

Kováč, M., Baráth, I., Harzhauser, M., Hlavatý, I., Hudáčková, N., 2004. Miocene depositional systems and sequence stratigraphy of the Vienna Basin. CFS Courier Forschungsinstitut Senckenberg, 187-212.

Kováč, M., Baráth, I., Kováčová-Slamková, M., Pipík, R., Hlavatý, I., Hudáčková, N., 1998. Late Miocene paleoenvironments and sequence stratigraphy: Northern Vienna Basin. Geologica Carpathica 49, 445-458.

Kováč, M., Márton, E., Oszczypko, N., Vojtko, R., Hók, J., Králiková, S., Plašienka, D., Klučiar, T., Hudáčková, N., Oszczypko-Clowes, M., 2017. Neogene palaeogeography and basin evolution of the Western Carpathians, Northern Pannonian domain and adjoining areas. Global and Planetary Change 155, 133-154.

Le Dortz, K., Meyer, B., Sébrier, M., Braucher, R., Nazari, H., Benedetti, L., Fattahi, M., Bourlès, D., Foroutan, M., Siame, L., Rashidi, A., Bateman, M.D., 2011. Dating inset terraces and offset fans along the Dehshir Fault (Iran) combining cosmogenic and OSL methods. Geophysical Journal International 185, 1147-1174.

Lee, E.Y., Wagreich, M., 2017. Polyphase tectonic subsidence evolution of the Vienna Basin inferred from quantitative subsidence analysis of the northern and central parts. International Journal of Earth Sciences 106, 687-705.

Lenhardt, W.A., Švancara, J., Melichar, P., Pazdírková, J., Havír̆, J., Sýkorová, Z., 2007. Seismic activity of the Alpine-Carpathian-Bohemian Massif region with regard to geological and potential field data. Geologica Carpathica 58, 397-412. 
Liang, L., Qiao, X., Dai, F., Zhong, N., Jiang, H., 2021: Seismically triggered soft-sediment deformation structures in Tashkorgan lacustrine sediments, northeastern Pamir, China. Quaternary International 604, 82-92.

Loope, D.B., 1984. Eolian origin of Upper Paleozoic sandstones, southeastern Utah. Journal of Sedimentary Petrology 54, 563-580.

Loope, D.B., Mason, J.A., Dingus, L., 1999. Lethal sandslides from Eolian dunes. Journal of Geology 107, 707-713.

Lunina, O.V., Gladkov, A.S., 2016. Soft-sediment deformation structures induced by strong earthquakes in southern Siberia and their paleoseismic significance. Sedimentary Geology 344, 5-19.

Maglay, J., Halouzka, R., Baňacký, V., Pristaš, J., Janočko, J., 1999. Neotektonická mapa Slovenska v mierke $1: 500000$ [EN: Neotectonic map of Slovakia in the scale $1: 500$ 000]. Ministry of environment of the SR, State Geological Survey of Dionýz Štúr, Bratislava, Slovakia, http://apl.geology.sk/temapy, Bratislava.

Maglay, J.E., 2009. Geological map of the Quaternary - Thickness map of the Quaternary cover. State Geological Survey of Dionýz Štúr, Bratislava, Slovakia, http://apl.geology.sk/temapy.

Maltman, A., 1994. The Geological Deformation of Sediments. Springer Science +Business Media, Dordrecht.

Moernaut, J., De Batist, M., Heirman, K., Van Daele, M., Pino, M., Brümmer, R., Urrutia, R., 2009. Fluidization of buried mass-wasting deposits in lake sediments and its relevance for paleoseismology: Results from a reflection seismic study of lakes Villarrica and Calafquén (South-Central Chile). Sedimentary Geology 213, 121-135.

Montenat, C., Barrier, P., Ott dEstevou, P., Hibsch, C., 2007. Seismites: An attempt at critical analysis and classification. Sedimentary Geology 196, 5-30.

Moravcová, M., Fordinál, K., 2010. OSL dating of eolic sands from Záhorská nížina Lowland. In: Kohút, M. (Ed.), Dating 2010, Dating of Minerals and Rocks, Metamorphic, Magmatic and Metallogenetic Processes, as Well as Tectonic Events. Conference Proceedings. State Geological Institute of Dionýz Štúr and Slovak Geological Society, Bratislava, pp. 25-26.

Moretti, M., 2000. Soft-sediment deformation structures interpreted as seismites in middle-late Pleistocene aeolian deposits (Apulian foreland, southern Italy). Sedimentary Geology 135, 167-179.

Moretti, M., Sabato, L., 2007. Recognition of trigger mechanisms for soft-sediment deformation in the Pleistocene lacustrine deposits of the Sant'Arcangelo Basin (Southern Italy): Seismic shock vs. overloading. Sedimentary Geology 196, 31-45.

Moretti, M., Tom van Loon, A.J., Liu, M., Wang, Y., 2014. Restrictions to the application of 'diagnostic' criteria for recognizing ancient seismites. Journal of Palaeogeography 3, 162173.

Morrocco, S.M., Ballantyne, C.K., Spencer, J.Q.G., Robinson, R.A.J., 2007. Age and significance of aeolian sediment reworking on high plateaux in the Scottish Highlands. Holocene 17, 349-360.

Mountney, N.P., Russell, A.J., 2004. Sedimentology of cold-climate aeolian sandsheet deposits in the Askja region of northeast Iceland. Sedimentary Geology 166, 223-244.

Mountney, N.P., Russell, A.J., 2009. Aeolian dune-field development in a water tablecontrolled system: Skeidarársandur, Southern Iceland. Sedimentology 56, 2107-2131.

Olley, J.M., De Deckker, P., Roberts, R.G., Fifield, L.K., Yoshida, H., Hancock, G., 2004. Optical dating of deep-sea sediments using single grains of quartz: A comparison with radiocarbon. Sedimentary Geology 169, 175-189. 
Owen, G., Moretti, M., Alfaro, P., 2011. Recognising triggers for soft-sediment deformation: Current understanding and future directions. Sedimentary Geology 235, 133-140.

Palumbo, L., Benedetti, L., Bourlès, D., Cinque, A., Finkel, R., 2004. Slip history of the Magnola fault (Apennines, Central Italy) from 36Cl surface exposure dating: evidence for strong earthquakes over the Holocene. Earth and Planetary Science Letters 225, 163176.

Plan, L., Grasemann, B., Spoetl, C., Decker, K., Boch, R., Kramers, J., 2010. Neotectonic extrusion of the Eastern Alps: Constraints from U/Th dating of tectonically damaged speleothems. Geology 38, 483-486.

Philip, H., Meghraoui, M., 1983. Structural analysis and interpretation of the surface deformations of the El Asnam earthquake of October 10, 1980. Tectonics 2, 17-49.Pollak, D., Gulam, V., Novosel, T., Avanić, R., Tomljenović, B., Hećej, N., Terzić, J., Stipčević, J., Bačić, M., Kurečić, T., Dolić, M., Bostjančić, I., Wacha, L., Kosović, I., Budić, M., Vukovski, M., Belić, N., Špelić, M., Brčić, V., Barbača, J., Kordić, B., Palenik, D., Filjak, R., Frangen, T., Pavić, M., Urumović, K., Sečanj, M., Matoš, B., Govorčin, M., Kovačević, M.S., Librić, L. 2021 (in press): The preliminary inventory of coseismic ground failures related to December 2020 - January 2021 Petrinja earthquake series. Geologia Croatica, doi: 10.4154/gc.2021.08

Prescott, J.R., Hutton, J.T., 1994. Cosmic ray contributions to dose rates for luminescence and ESR dating: Large depths and long-term time variations. Radiation Measurements 23, 497-500.

Prescott, J.R., Stephan, L.G., 1982. The contribution of cosmic radiation to the environmental dose for thermoluminescent dating. Latitude, altitude and depth dependences. PACT 6, 17-25.

Pye, K., Tsoar, H., 2009. Aeolian sand and sand dunes. Springer, Berlin.

R Core Team 2020. R: A language and environment for statistical computing. R Foundation for Statistical Computing, Vienna, Austria. Available online: http://www.rproject.org/index.html (Accessed 12 May 2021)

R.Luminescence project, 2021. Available online: http://rlum.geographie.unikoeln.de:9418/packages/RLumShiny/inst/shiny/abanico/ (Accessed 2 November 2021)

Rodríguez-López, J.P., Wu, C., 2020. Recurrent deformations of aeolian desert dunes in the cretaceous of the South China Block: Trigger mechanisms variability and implications for aeolian reservoirs. Marine and Petroleum Geology 119, 104483.

Ruszkiczay-Rüdiger, Z., Fodor, L.I., Horváth, E., 2007. Neotectonics and Quaternary landscape evolution of the Gödöllö Hills, Central Pannonian Basin, Hungary. Global and Planetary Change 58, 181-196.

Ruszkiczay-Rüdiger, Z., Kern, Z., 2016. Permafrost or seasonal frost? A review of paleoclimate proxies of the last glacial cycle in the East Central European lowlands. Quaternary International 415, 241-252.

Ruz, M.H., Allard, M., 1995. Sedimentary structures of cold-climate coastal dunes, Eastern Hudson Bay, Canada. Sedimentology 42, 725-734.

Sağlam Selçuk, A., Kul, A.Ö., 2021. Long-term slip rate estimation for Erciş Fault in East Anatolian Compressive Tectonic Block from geologic and geomorphologic field evidence. Geological Journal 56, 5290-5310.

Salcher, B.C., Faber, R., Wagreich, M., 2010. Climate as main factor controlling the sequence development of two Pleistocene alluvial fans in the Vienna Basin (eastern Austria) - A numerical modelling approach. Geomorphology 115, 215-227.

Salcher, B.C., Frank-Fellner, C., Lomax, J., Preusser, F., Ottner, F., Scholger, R., Wagreich, M., 2017. Middle to Late Pleistocene multi-proxy record of environmental response to 
climate change from the Vienna Basin, Central Europe (Austria). Quaternary Science Reviews 173, 193-210.

Salcher, B.C., Meurers, B., Smit, J., Decker, K., Hlzel, M., Wagreich, M., 2012. Strike-slip tectonics and Quaternary basin formation along the Vienna Basin fault system inferred from Bouguer gravity derivatives. Tectonics 31, Tc3004.

Salcher, B.C., Wagreich, M., 2010. Climate and tectonic controls on Pleistocene sequence development and river evolution in the Southern Vienna Basin (Austria). Quaternary International 222, 154-167.

Sebe, K., Roetzel, R., Fiebig, M., Lüthgens, C., 2015. Pleistocene wind system in eastern Austria and its impact on landscape evolution. Catena 134, 59-74.

Seppälä, M., 2004. Wind as a Geomorphic Agent in Cold Climates. Cambridge University Press, Cambridge, 358 p.

Shanmugam, G., 2017. Global case studies of soft-sediment deformation structures (SSDS): Definitions, classifications, advances, origins, and problems. Journal of Palaeogeography 6, 251-320.

SLOVEC, 2011. Slovak Earthquake Catalogue (Version 2011). Data File of the Geophysical Institute. Slovak Academy of Sciences, Bratislava, Slovakia.

Steidtmann, J.R., 1973. Ice and snow in eolian sand dunes of southwestern Wyoming. Science 179, 796-798.

Steidtmann, J.R., 1982. Structures in the moist, cold-climate sand dunes of southwestern Wyoming, Special Paper of the Geological Society of America, pp. 83-87.

Stokes, S., Maxwell, T.A., Haynes Jr., C.V., Horrocks, J.L., 1998. Latest Pleistocene and Holocene sand-sheet construction in the Selima Sand Sea, Eastern Sahara. In: Alsharhan, AS., Glennie, K.W., Whittle, G.L., Kendall, C.G.St.C. (Eds.), Quaternary Deserts and Climatic Change. AA Balkema, Rotterdam and Brookfield VT, pp. 175-183.

Strauss, P., Harzhauser, M., Hinsch, R., Wagreich, M., 2006. Sequence stratigraphy in a classic pull-apart basin (Neogene, Vienna Basin). A 3D seismic based integrated approach. Geologica Carpathica 57, 185-197.

Szczygieł, J., Sobczyk, A., Hercman, H., Mendecki, M.J., Gąsiorowski, M., 2021. Damaged Speleothems and Collapsed Karst Chambers Indicate Paleoseismicity of the NE Bohemian Massif (Niedźwiedzia Cave, Poland). Tectonics 40, e2020TC006459.

Štěpančíková, P., Hók, J., Nývlt, D., Dohnal, J., Sýkorová, I., Stemberk, J., 2010. Active tectonics research using trenching technique on the south-eastern section of the Sudetic Marginal Fault (NE Bohemian Massif, central Europe). Tectonophysics 485, 269-282.

Štěpančíková, P., Stemberk, J., Vilímek, V., Košták, B., 2008. Neotectonic development of drainage networks in the East Sudeten Mountains and monitoring of recent fault displacements (Czech Republic). Geomorphology 102, 68-80.

Šujan, M., Braucher, R., Šujan, M., Hók, J., Povinec, P.P., Šipka, F., Rugel, G., Scharf, A., 2019. The tectono-sedimentary evolution of a major seismogenic zone with low slip rate activity: A geochronological and sedimentological investigation of the Dobrá Voda Depression (Western Carpathians). Sedimentary Geology 383, 248-267.

Tary, J.B., Apoloner, M.T., Bokelmann, G., 2015. Earthquake interactions during the 2013 Ebreichsdorf aftershock sequence. Austrian Journal of Earth Sciences 108, 209-218.

Taşgın, C.K., Orhan, H., Türkmen, İ., Aksoy, E., 2011. Soft-sediment deformation structures in the late Miocene Şelmo Formation around Adiyaman area, Southeastern Turkey. Sedimentary Geology 235, 277-291.

Tikhomirov, D., Akçar, N., Ivy-Ochs, S., Alfimov, V., Schlüchter, C., 2014. Calculation of shielding factors for production of cosmogenic nuclides in fault scarps. Quaternary Geochronology 19, 181-193. 
Van Dijk, P.M., Stroosnijder, L., De Lima, J.L.M.P., 1996. The influence of rainfall on transport of beach sand by wind. Earth Surface Processes and Landforms 21, 341-352.

van Vliet-Lanoë, B., Magyari, A., Meilliez, F., 2004. Distinguishing between tectonic and periglacial deformations of quaternary continental deposits in Europe. Global and Planetary Change 43, 103-127.

Vandenberghe, J., 2013. Grain size of fine-grained windblown sediment: A powerful proxy for process identification. Earth-Science Reviews 121, 18-30.

Waller, R.I., Murton, J.B., Kristensen, L., 2012. Glacier-permafrost interactions: Processes, products and glaciological implications. Sedimentary Geology 255-256, 1-28.

Ward, I.A.K., Nanson, G.C., Head, L.M., Fullagar, R.L.K., Price, D.M., Fink, D., 2005. Late Quaternary landscape evolution in the Keep River region, northwestern Australia. Quaternary Science Reviews 24, 1906-1922.

Weissl, M., Hintersberger, E., Lomax, J., Lüthgens, C., Decker, K., 2017. Active tectonics and geomorphology of the Gaenserndorf Terrace in the Central Vienna Basin (Austria). Quaternary International 451, 209-222.

Wintle, A.G., Murray, A.S., 2006. A review of quartz optically stimulated luminescence characteristics and their relevance in single-aliquot regeneration dating protocols. Radiation Measurements 41, 369-391.

Youssef, H., Hanna, A., 1988. Behavior of Frozen and Unfrozen Sands Triaxial Testing. Transportation Research Record 1190, 57-64. 